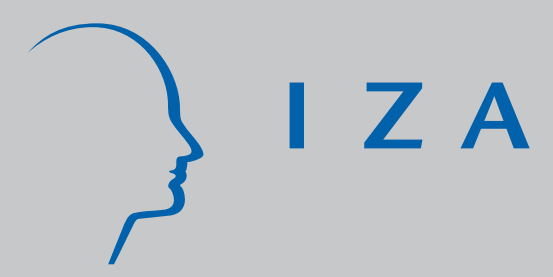

IZA DP No. 5910

Tax Policy and Income Inequality in the U.S., 1978-2009: A Decomposition Approach

Olivier Bargain Mathias Dolls Herwig Immervoll Dirk Neumann

August 2011
Andreas Peichl

Nico Pestel

Sebastian Siegloch 


\section{Tax Policy and Income Inequality in the U.S., 1978-2009: A Decomposition Approach}

\author{
Olivier Bargain \\ UC Dublin, IZA and CEPS/INSTEAD
}

Mathias Dolls

University of Cologne and IZA

\author{
Herwig Immervoll \\ OECD, ISER and IZA
}

Dirk Neumann

University of Cologne and IZA

\author{
Andreas Peichl \\ IZA, University of Cologne, ISER and CESifo
}

Discussion Paper No. 5910

August 2011

Sebastian Siegloch

University of Cologne and IZA

\author{
Nico Pestel \\ University of Cologne and IZA
}

University of Cologne and IZA 


\section{ABSTRACT \\ Tax Policy and Income Inequality in the U.S., 1978-2009: A Decomposition Approach ${ }^{*}$}

We assess the effects of U.S. tax policy reforms on inequality by applying a new decomposition method that allows us to disentangle mechanical effects due to changes in pre-tax incomes from direct effects of policy reforms. While tax reforms implemented under Democrat administrations, in particular the EITC reforms in the 1990s and the ARRA in 2009, had an equalizing effect at the lower half of the distribution, the disequalizing effects of Republican reforms are due to tax cuts for high-income families. As a consequence of partisan politics, overall policy effects almost cancel out over the whole time period.

JEL Classification: $\quad$ H23, H31, H53, P16

Keywords: $\quad$ tax policy, inequality, redistribution, political economy, Great Recession

Corresponding author:

Andreas Peichl

IZA

P.O. Box 7240

53072 Bonn

Germany

E-mail: peichl@iza.org

\footnotetext{
* This paper uses TAXSIM v9. TAXSIM is continually being improved and updated and the results presented here represent the best available at the time of writing. Our version of TAXSIM is based on the IPUMS CPS, an integrated set of data of the March Current Population Survey which is conducted jointly by the U.S. Census Bureau and the Bureau of Labor Statistics.

We would like to thank Jeff Larrimore for providing us with a series of cell means for individuals in the CPS with topcoded incomes as well as Daniel Feenberg for granting us access to NBER's TAXSIM and helping us with our simulations, in particular the imputation of itemized deductions. We are grateful to James Alm, Denvil Duncan, Andrew Oswald, Emmanuel Saez, James Sullivan, Tim Smeeding, Sally Wallace, as well as seminar and conference participants in Bonn (IZA), Canazei (IT6) and Stockholm (IMA) for helpful comments and suggestions. We gratefully acknowledge financial support from the Organisation for Economic Co-operation and Development (OECD). Peichl is grateful for financial support by Deutsche Forschungsgemeinschaft (PE1675). Any errors as well as the views presented in this paper are the responsibility of the authors alone. In particular, the views do not represent the official positions of organisations to which the authors are affiliated.
} 


\section{Introduction}

Over the past decades, household incomes have become more unequally distributed in most OECD countries. The United States is among the countries recording the largest levels and increases in inequality (cf. OECD 2008). The usual approach for evaluating the role of taxation as a driver of overall inequality trends is to compare income inequality measures before and after taxes (see e.g. Gottschalk and Smeeding 1997 or Heathcote et al. 2010). However, tax burdens and their impact on the income distribution are determined by both tax schedule and tax base. For instance, a given progressive income tax schedule redistributes more when the distribution of taxable incomes becomes more dispersed, and very little if everybody earns about the same (Musgrave and Thin 1948 and Dardanoni and Lambert 2002). At the same time, the U.S. tax system has seen a large number of changes due to policy reforms (such as lower marginal tax rates and a reduced number of tax brackets in the 1980s or a more generous Earned Income Tax Credit, EITC, in the 1990s). Given the importance of the distribution of market income for redistribution, it is however unclear how much of an observed change in tax burdens is due to policy reforms and what part is due to other factors, notably the underlying distribution of market income (as well as other tax-relevant population characteristics, such as family structures). ${ }^{1}$

We assess the effect of tax reforms on economic inequality in the U.S. over the 1978-2009 period. We pay special attention to separating the direct effects of policy reforms from other factors, including indirect policy effects due to behavioral responses (Poterba 2007). To isolate the pure policy effects, we perform a series of detailed counterfactual simulations that show what the income distribution would have been if either tax policy or, alternatively, the distribution of the tax base had remained unchanged between two given years. In combination with a decomposition analysis based on Shorrocks (1999)'s reinterpretation of the Shapley value, these simulation results enable us to split changes in inequality into a direct tax policy effect and other factors which impact on income distribution. ${ }^{2}$ By repeating the analysis for each year, this method allows us to reassess whether major U.S. tax reforms during the past three decades have either slowed or exacerbated the trend towards greater income inequality.

This paper adds to the literature analyzing pre- and post-tax income inequality in the U.S. since the late 1970s by using micro data from the Current Population Survey

\footnotetext{
${ }^{1}$ Note that even without changes to the tax schedule, the tax system becomes more progressive if taxable incomes grows faster than the indexation of tax brackets - this is known as 'bracket creep' (see e.g. Saez 2003 and Immervoll 2005).

${ }^{2}$ Our approach formalizes analyses of policy effects, as performed for instance by Clark and Leicester (2004) for the United Kingdom. See also Bargain and Callan (2010) for France and Ireland. A related concept for the comparison of tax regimes with respect to progressivity - the transplant-andcompare procedure (Dardanoni and Lambert 2002) - is applied by Lambert and Thoresen (2009) for Norway. They isolate the tax policy effect by comparing pre-tax income distributions which have been adjusted to a common base.
} 
(CPS). ${ }^{3}$ Our analysis is a natural follow-up of the study by Piketty and Saez (2007). While they use the NBER's TAXSIM calculator to compute changing tax burdens over time and assess their impact on changes in progressivity of the federal income tax system, we investigate their impact on changes in inequality. The novelty of our paper is that we explicitly distinguish between the measured redistributive effect of tax reforms (as a combination of tax policy and tax base distribution changes) on the one hand and the pure policy effect on the other hand. The former emerges from simple comparisons of pre- and post-tax income, whereas the latter results from our decomposition analysis based on counterfactual policy simulations using the TAXSIM model. We quantify the distributional impact of specific tax policy changes and compare its magnitude to other drivers of inequality changes.

Our main findings are as follows. The increase in post-tax income inequality was slower than that of pre-tax inequality indicating that the redistributive role of the tax system has increased over time. However, our decomposition reveals that most of this increase in redistribution was not due to the policy effect but a mechanical consequence of the rising inequality in pre-tax income. Indeed, the effects of policy changes more or less canceled out over the period as a whole - which is a direct consequence of partisan politics. Our findings are in line with popular perceptions regarding the political cycle, with disequalizing (equalizing) effects observed for policy changes implemented during Republican (Democrat) administrations (see Bartels 2008). The results for some subperiods show large effects for actual policy changes - sometimes accounting for more than 50 percent of the increase in post-tax inequality (Tax Reform Act of 1986). There are also significant differences between results for the lower and upper parts of the distribution. Policy reforms enacted in the early and mid 1990s reduced income gaps at the bottom to below their 1978 values. The equalizing effect of tax policy on inequality at the lower half of the distribution is maintained until the end of the observation period and even enforced by provisions enacted through the American Recovery and Reinvestment Act. By contrast, no equalizing effects of policies can be discerned for the upper part of the distribution. Instead, for the period as a whole, tax policy changes affecting top-income earners appear to have slightly exacerbated trends towards widening income gaps at the top.

The rest of the paper is organized as follows. Section 2 reviews the existing U.S. income inequality literature and particularly focuses on the impact of tax policy on the income distribution. The decomposition analysis, the data and income concepts are described in section 3. Results are presented in section 4. Section 5 concludes.

\footnotetext{
${ }^{3}$ See e.g. Heathcote et al. (2010), Meyer and Sullivan (2010), Meyer and Sullivan (2011) for studies also based on CPS data and Piketty and Saez (2007) who use tax return data.
} 


\section{Literature}

Rising income inequality in the U.S. has stimulated a large body of research examining the underlying driving factors. In this literature, several strands have emerged which focus on different types of inequality. While the focus of this paper is on redistribution and the impact of tax policy on trends in post-tax income inequality, the latter cannot be comprehensively assessed without taking into account trends in pre-tax inequality.

The development of wage and earnings inequality has triggered a vast amount of research. A key result of the literature is that wage inequality increased substantially during the late 1970s and early 1980s. For instance, Gottschalk and Danziger (2005) find that the development of male wage and family income inequality were largely comparable over the period 1975 to $2002 .{ }^{4}$ Autor et al. (2008) provide an overview of the literature on U.S. wage inequality and discuss if the substantial increase since the 1980s can be considered as an episodic event or a continuous development. ${ }^{5}$

Two explanations for a rising wage dispersion are globalization and skill-biased technological change. Both may have a negative effect on wages of low-skilled workers, but a positive one on those of the high-skilled. While there is a direct channel from individual wage to family income inequality, other trends than those affecting individual wage inequality clearly coexist and impact trends in family income. Among those, the labor force participation of women, assortative mating and other aspects of family formation have been discussed in the literature. ${ }^{6}$

Moving from the individual to the household level, income inequality widened in the 1970s (cf. Lindert 2000) and continued to rise sharply in the 1980s. Studies using the CPS find that total income inequality, i.e. inequality in pre-tax, post-transfer income rose sharply in the $1980 \mathrm{~s}$, and that this growth continued at a reduced pace in the 1990s and early 2000s. ${ }^{7}$ Evidence for the trend in pre-tax income inequality since the 1990s that seems to be contrasting at first glance, however, is reported by Piketty and Saez (2003) (updated 2008) who build series of top income shares based

\footnotetext{
${ }^{4}$ They further report that male wage and earnings inequality had similar trends, though earnings inequality showed a cyclical pattern due to changes in hours worked at the bottom of the distribution. Contrary, caused by the increase in hours worked of females at the bottom of the distribution, female earnings inequality decreased over the last three decades and thus reversed the trend of growing wage inequality.

${ }^{5}$ See e.g. Card and DiNardo (2002) for the former argument, whereas Autor et al. (2008) find support for the latter. They show that while male wage inequality in the lower half of the distribution grew strongly in the first half of the 1980s and declined afterwards, inequality in the upper half of the distribution kept growing in the 1990s and 2000s.

${ }^{6}$ It is beyond the scope of this paper to provide a general discussion of the sources contributing to an increase in inequality or to quantify the contributions of certain factors affecting inequality (see e.g. Gottschalk and Smeeding (1997) for the first and Burtless (1999), Daly and Valletta (2006) or Larrimore (2010) for the latter point).

${ }^{7}$ See e.g. Gottschalk and Danziger (2005), Burkhauser et al. (2009), Meyer and Sullivan (2010), Heathcote et al. (2010), Burkhauser et al. (2011b). Differences between these studies exist with regard to the definition of the income unit (family vs. household), sample selection (full population vs. working-age population) and whether or not topcoding in the public-use CPS is accounted for.
} 
on tax return data from the Internal Revenue Service (IRS). They find that the share of income held by the richest groups grew in the 1990's, and with the exception of the period 2000-2002, continued to rise in the following years. ${ }^{8}$ Burkhauser et al. (2011a) seek to reconcile some of the findings from these two data sources. They use internal CPS data which are - compared with public-use CPS - much less affected by topcoding (although a number of other measurement and conceptual differences remain) and apply similar income definitions as Piketty and Saez (2003) do, namely pre-transfer, tax-unit income. They conclude that the rise in inequality from 1993 onwards is mainly due to gains made by the top 1 percent of the income distribution.

Recent studies which analyze trends in post-tax income inequality and redistribution in the U.S. are Meyer and Sullivan (2010) and Heathcote et al. (2010). The former find that post-tax income inequality started to increase later (in the late 1970s) than that of pre-tax income and that its increase in the 1980s occurred at a slower rate. Somewhat contrasting, one finding of the latter is that trends in pre- and post-tax income inequality had been similar in the 1980s, but the gap widened (and redistribution therefore increased) in the 1990s. ${ }^{9}$ A large part of redistribution in the U.S. takes place through tax expenditures. Since 1986, the Earned Income Tax Credit (EITC) has been extended in several steps and nowadays represents an important element of the federal tax system in terms of redistribution to the working-poor. ${ }^{10}$ However, the redistributive capacity of the income tax system does depend - besides tax expenditures - on many factors such as the degree of progressivity, the relative importance of certain components and the distribution of pre-tax income. ${ }^{11}$

Our paper contributes to the strand of the literature which examines the impact of tax policy on post-tax income inequality. By extracting the direct policy effect through counterfactual simulations, we complement analyses conducted by Piketty and Saez (2007) or the Congressional Budget Office (2010). In these studies, shares of post-tax income and average federal tax rates are calculated for all income groups and similar time periods, but the estimates do not allow to isolate the direct policy effect since they reflect both legislative changes as well as other factors which influence tax rates. Some studies have conducted so-called "what if" calculations (cf. Poterba (2007), p.

\footnotetext{
${ }^{8}$ Further studies relying on IRS tax return data are Slemrod (1992), Feenberg and Poterba (1993), DeBacker et al. (2010) and Bakija et al. (2010) who, in particular, look at top incomes, though this list is not exhaustive.

${ }^{9}$ Note that a key difference between these two studies is the selection of the sample. While Meyer and Sullivan (2010) use the full CPS sample, the household-level sample in Heathcote et al. (2010) is restricted to those households with at least one member in working-age.

${ }^{10}$ See e.g. Hotz and Scholz (2003), Meyer (2010) and Eissa and Hoynes (2011) who document the growing redistributive impact of this program.

${ }^{11}$ For studies examining the progressivity of the tax system, see e.g. Kasten et al. (1994), Bishop et al. (1997), Alm et al. (2005) and Piketty and Saez (2007). The latter find that the progressivity of the overall federal tax system declined substantially at the top of the income distribution since the 1960s. Mitrusi and Poterba (2000) describe the growing importance of payroll taxes relative to the income tax since the early 1980s.
} 
630) but to the best of our knowledge, none of these papers have sought to identify a policy effect on a year-by-year basis over a long time period. We are aware of two contributions which explicitly consider - via counterfactual simulations - the impact of tax policy on the post-tax income distribution. In an analysis of policy changes during the 1980s, Gramlich et al. (1993) apply tax and transfer policies of 1980 and 1985 to the pre-tax income distribution of 1990. They report that 16 percent of the increase in the Gini coefficient from 1980 to 1990 are due to changes in taxes and transfers, although the exact scope of their study in terms of simulated taxes and transfers is not clear. More recently, Poterba (2007) conducts conceptually similar policy swaps by applying 2004 effective tax rates to the 2000 pre-tax income distribution and vice versa and examines the resulting effects on the share of post-tax (but before payroll tax) income accruing to various income groups. A key finding from this analysis is that the impact of changes in the pre-tax income distribution is approximately four times as large as the policy effect of changes in effective tax rates. ${ }^{12}$

\section{Methodology}

\subsection{Decomposition}

We follow the decomposition approach by Bargain and Callan (2010). Consider a data matrix $y$ containing information on individuals' pre-tax income from different sources as well as various individual and household characteristics which are relevant for the calculation of income and payroll taxes. The tax function $d$ represents the rules and structure of the tax system (e.g., marginal tax and contribution rates) while vector $p$ accounts for all the monetary parameters (e.g., tax band limits). In this way, the distribution of post-tax income is represented by $d_{i}\left(p^{j}, y^{l}\right)$ for tax rules of year $i$, tax parameters of year $j$ and nominal incomes of year $l$. We shall also consider the possibility of nominally adjusting income levels and/or parameters $p$ by an uprating factor $\alpha$. For instance, the counterfactual situation $d_{t+1}\left(p^{t+1}, \alpha^{t+1} y^{t}\right)$ represents posttax incomes obtained by applying tax rules and parameters of year $t+1$ on year $t$ data nominally adjusted to year $t+1$. This backdrop, where the new policy is evaluated while holding the population constant, is used in the decomposition below. Symmetrically, we may evaluate the distribution obtained with the initial policy applied to the new population. For this, we need to construct a counterfactual $d_{t}\left(\alpha^{t+1} p^{t}, y^{t+1}\right)$ where tax

\footnotetext{
${ }^{12}$ Further studies examining the degree of redistribution of the U.S. income tax system by means of policy swaps are Kasten et al. (1994), Mitrusi and Poterba (2000), Alm et al. (2005), Leigh (2008) and Meyer (2010). However, these studies do not quantify how much of an observed change in post-tax income inequality is due to policy changes. Instead, the focus of these contributions is on the changing importance of income and payroll taxes over time (Mitrusi and Poterba 2000), on the progressivity of the income tax (Kasten et al. 1994 and Alm et al. 2005), the redistributiveness of state taxes (Leigh 2008) and the distributional effect of the EITC reform enacted through the American Recovery and Reinvestment Act of 2009 (Meyer 2010).
} 
parameters are uprated using the same factor $\alpha^{t+1}$ as used to scale up the distribution of gross income between period $t$ and $t+1 .^{13}$ As further explained below, policy changes under study possibly combine changes in policy structure $d$ and changes in parameters $p$ (the 'uprating policy').

In the empirical part, we are interested in relative inequality indices $I$, computed as a function $I\left[d_{i}\left(p^{j}, y^{l}\right)\right]$ of the simulated distribution of post-tax income. The advantage of the present approach is that we may use any inequality measure and not only those with specific properties (i.e., decomposable indices). In general, it is possible to decompose any scalar $I$, e.g. average and effective marginal tax rates, measures of tax redistribution or automatic stabilization. Characterize total change $\Delta I$ in the inequality index $I$ between initial and final period as

$$
\Delta=I\left[d_{t+1}\left(p^{t+1}, y^{t+1}\right)\right]-I\left[d_{t}\left(p^{t}, y^{t}\right)\right]
$$

and notice that the last term can also be written $I\left[d_{t}\left(\alpha^{t+1} p^{t}, \alpha^{t+1} y^{t}\right)\right]$ since function $d$ is linearly homogenous in $p$ and $y .{ }^{14}$ Then, the total change between periods $t$ and $t+1$ can be decomposed into the contributions of changing policy and of changing data (i.e., changing the underlying gross income distribution due to all effects not directly due to tax reforms). The policy effect can be assessed on end period data $y^{t+1}$, and in this case, the data or "other" effect is assessed on the base period tax system, yielding the decomposition I:

$$
\begin{aligned}
\Delta I= & \underbrace{I\left[d_{t+1}\left(p^{t+1}, y^{t+1}\right)\right]-I\left[d_{t}\left(\alpha^{t+1} p^{t}, y^{t+1}\right)\right]}_{\text {policy effect I }} \\
& +\underbrace{I\left[d_{t}\left(\alpha^{t+1} p^{t}, y^{t+1}\right)\right]-I\left[d_{t}\left(\alpha^{t+1} p^{t}, \alpha^{t+1} y^{t}\right)\right]}_{\text {other effect I }}
\end{aligned}
$$

Notice that in this case, base period tax parameters are applied to end period data $y^{t+1}$ after nominal adjustment, i.e., writing parameters as $\alpha^{t+1} p^{t}$. Symmetrically, the decomposition can be written as a policy effect assessed on base year data followed by a change in underlying data conditional on the new policy. This decomposition II is thus written as:

\footnotetext{
${ }^{13} \mathrm{~A}$ measure $d_{t}\left(p^{t}, y^{t+1}\right)$ would not be consistent since base-period parameters would be artificially applied to end-period income levels. For instance, previous tax band thresholds would be applied to new and possibly higher income levels, thereby generating artificial 'fiscal drag' (see Saez 2003 or Immervoll 2005).

${ }^{14}$ Converting tax parameters and income from dollars into euros does not change the relative location of households in the distribution of post-tax income.
} 


$$
\begin{aligned}
\Delta I= & \underbrace{I\left[d_{t+1}\left(p^{t+1}, y^{t+1}\right)\right]-I\left[d_{t+1}\left(p^{t+1}, \alpha^{t+1} y^{t}\right)\right]}_{\text {policy effect II }} \\
& +\underbrace{I\left[d_{t+1}\left(p^{t+1}, \alpha^{t+1} y^{t}\right)\right]-I\left[d_{t}\left(\alpha^{t+1} p^{t}, \alpha^{t+1} y^{t}\right)\right]}_{\text {other effect II }} .
\end{aligned}
$$

In this case, the end-period tax system is evaluated on nominally-adjusted base-period data $\alpha^{t+1} y^{t}$.

As the decompositions are path dependent, we simply average policy and other effects respectively over the decompositions I and II. Doing so corresponds to the suggestion of Shorrocks (1999) of using a Shapley value procedure whereby the contribution of a given factor (to a change in the statistic $I$ ) is obtained by extracting the marginal contribution of eliminating this factor and averaging these marginal contributions over all possible elimination sequences. In the empirical sections, however, we shall verify that results based on decompositions I and II are not too different to each other and to the average Shapley decomposition result.

In the decompositions, it is important to understand that the nominally-adjusted tax schedule, $\alpha^{t+1} p^{t}$, is not identical to the actual set of parameters $p^{t+1}$ as decided by the policy-maker. Hence, the policy effect does not only capture the effect of changes in policy structure $\left(d_{t}\right.$ to $\left.d_{t+1}\right)$ on the income distribution but also the actual uprating policy (shift from $p^{t}$ to $p^{t+1}$ ) against a scenario where parameters are adjusted in line with the uprating factor $\alpha^{t+1}$. The way tax brackets are uprated by governments can have important implications for the income distribution and public spending in the long run. Standard practice consists in one of the three following options: (1) no uprating, (2) uprating according to the level of price inflation, (3) uprating according to the level of earnings growth. With non-indexation of tax brackets in progressive systems, or price indexation when incomes rise faster than prices, the total number of tax payers (and the number of higher-rate taxpayers) increases. This phenomenon of 'fiscal drag' or 'bracket creep' must affect the final distribution of post-tax income (see Saez 2003 and Immervoll 2005). In our empirical application, we use changes in the consumer price index. This reference situation is extensively used in policy analyses of tax reforms (cf., discussion in Clark and Leicester 2004). This choice is also justified on historical ground as it aims to guarantee some continuity in the evaluation of policies (see Sutherland et al. 2008). In a robustness check (see section 4.3), we rely on a more conservative approach based on nominal wage growth, i.e., a distributionally-neutral backdrop (cf. Bargain and Callan 2010). A related issue is the question whether it is interesting to further decompose our policy effect into the contributions of structural changes and uprating policy, respectively. For some types of reforms, these two components are usually intertwined in a way that makes the 
distinction irrelevant and arbitrary. For instance, a change in the maximum amount of EITC, other monetary parameters being held constant, also entails a necessary change in the phase-in and phase-out rates. Classifying the former as uprating policy change and the latter as "structural" policy change is probably meaningless. However, in the empirical results, we should pay attention to periods where uprating policies were subject to specific changes, typically price-indexation policies during high inflation periods.

With the present approach, we are able to account for direct effects of tax policy changes but don't consider the indirect response to changes in tax policy (Poterba (2007), p. 632-633, Slemrod (1992), p. 108). ${ }^{15}$ For instance, reforms may affect labor supply behavior and hence the distribution of gross income. In particular, the EITC reforms have been shown to change substantially participation rates among married couples and single mothers (cf., Eissa and Hoynes (2006), among others). In addition to adjustments in participation or work hours, tax reforms may affect many different other margins (e.g., tax evasion) and change the tax base at all levels and in particular at the top of the distribution. This point is investigated in the new tax responsiveness literature (Feldstein 1995, Gruber and Saez 2002 and Saez et al. 2011). Hence, further research may account for this indirect effect, which could be handled in the present decomposition framework. However, as we look at year-to-year changes, the "other effect" should more or less equal the indirect, behavioral effect as other, structural changes are unlikely to occur in the short-run.

\subsection{Data}

Several data sources have been used in studies focusing on the impact of taxation on income inequality, in particular tax return data (e.g. Piketty and Saez 2007) and household surveys such as the CPS (e.g. Alm et al. 2005). It is well-known that there are pros and cons for both types of data sources (Poterba 2007). In brief, tax return data allow to precisely calculate top income shares, but do not contain information about non-filing households (typically at the bottom of the distribution) and lack certain (tax-relevant) components of household income. The CPS is a rich microdata set of U.S. households and a primary data source for investigating income and distribution trends. It is also the source for official U.S. government statistics on (un)employment and poverty. However, it does not contain information with respect to itemized deductions which might affect our results. Further, for confidentiality reasons, the U.S. Census Bureau "top codes" (i.e. censors) all income sources, with differences in methods between some years. This can cause a downward bias of income

\footnotetext{
${ }^{15}$ Piketty and Saez (2007), p.9, however, argue that given the controversy about behavioral responses to taxation "[...] considering the basic case with no behavioral response is a useful starting place".
} 
inequality estimates.

In this study, we use data from IPUMS-CPS (Integrated Public Use Microdata Series, Current Population Survey) which is a harmonized set of data of the Annual Social and Economic 'March' Supplement (ASEC) comprising the years 1962-2010. The CPS is a monthly U.S. household survey representative of the civilian non-institutional population and jointly conducted by the U.S. Census Bureau and the Bureau of Labor Statistics. Importantly, we are able to overcome the shortcomings associated with this data source. First, to alleviate the problem of topcoding, we use an extended series of cell means constructed from internal CPS (see Larrimore et al. 2008 and Burkhauser et al. 2010) which enables us to closely replicate inequality trends found in the internal CPS data. ${ }^{16}$ Further, we focus our analysis on percentile ratios such as the 90/10 ratio which is standard in the U.S. income inequality literature (see e.g. Gottschalk and Danziger 2005, Meyer and Sullivan 2010). Second, for the imputation of itemized deductions we use data from the Internal Revenue Service (IRS). These are representative micro-level tax return files compiled annually by the Statistics of Income (SOI) division of the IRS. In a sensitivity check, we explore how our results are affected by this imputation (see section 4.3).

\subsection{Sample selection, income concepts and the calculation of counterfactual scenarios}

Our sample solely includes non-elderly households meaning that at least one member of the household is in working-age, i.e. between the ages of 15 and 64 . The motivation for this sample selection is driven by the fact that our analysis entirely focuses on taxpolicy and does not consider the policy effect of transfers targeted to the elderly. In a robustness check, we recalculate our results for the full population. We use the square root of household size as equivalence factor in order to account for economies of scale within households (see e.g. Atkinson et al. 1995 or Burkhauser et al. 2009).

Throughout this paper, we focus on pre- and post-tax income inequality which are defined as commonly done in the literature (e.g., Heathcote et al. 2010 and Meyer and Sullivan 2010). Pre-tax income is taken from the data and follows the Census definition of money income that is used to measure poverty and inequality. It is computed as the sum of market income (sum of pre-tax wage and salary income, business and farm income, interest, investment, and rental income) plus private (e.g. alimony) and public transfers (e.g. unemployment benefits, Social Security, SSI, welfare payments). Post-tax income is defined as pre-tax income minus the simulated components of the income tax system including federal income taxes, state income taxes, employee social

\footnotetext{
${ }^{16}$ Note that even internal CPS data is censored. However, Burkhauser et al. (2011a) show that with internal CPS data, it is possible to match top income shares reported by Piketty and Saez (2003) who use Internal Revenue Service (IRS) tax return data.
} 
insurance contributions (payroll taxes), and tax credits (e.g. EITC).

For the calculation of the baseline as well as for counterfactual scenarios and the isolation of the tax policy effect - i.e. applying policy parameters from the base period to the population of the end period or policy parameters from the end period to the population of the base period - we use NBER's simulation model TAXSIM. ${ }^{17}$ The simulation approach allows conducting a controlled experiment by changing the parameters of interest while holding everything else constant which avoids endogeneity problems when identifying the effects of the policy reform under consideration (cf. Bourguignon and Spadaro 2006). When assessing the isolated role of tax policy on income inequality, we are thus able to account for changes in federal and state level income taxes as well as payroll taxes and tax credits such as the EITC. Our analysis spans the period 1978 until 2009.

\subsection{Tax history}

In this section, we briefly outline the major changes in the U.S. federal income tax system from 1978 until 2009 which are also summarized in Table 1. We concentrate on large legislative changes which drive the tax policy effect described later in this section. Reforms of interest are the Revenue Act of 1978 (RA78), the Economic Recovery Tax Act of 1981 (ERTA81), the Tax Reform Act of 1986 (TRA86), the Omnibus Budget Reconciliation Act of 1990 and 1993 (OBRA90 and OBRA93), the Taxpayer Relief Act of 1997 (TRA97), the Economic Growth and Tax Relief Reconciliation Act of 2001 (EGTRRA01), the Jobs and Growth Tax Relief Reconciliation Act of 2003 (JGTRRA03) and the American Recovery and Reinvestment Act of 2009 (ARRA09).

The aim of RA78 was to enhance real GDP growth (Romer and Romer 2009). For that purpose, by widening tax brackets and reducing the number of tax rates, individual taxes were reduced. Further, at that time inflation was relatively high and individual income tax parameters were not fixed for inflation so that "bracket creep" led to increases in income tax revenue as a percentage of GDP. RA78 to some extent attenuated this effect and caused a yearly reduction in tax revenue of on average 0.83 percent of GDP in the four years after the reform (c.f. Tempalski (2006) for estimates of revenue effects mentioned in this section).

ERTA81 introduced the indexation of individual income tax parameters which became effective in 1985. Tax cuts were phased in over the years 1982-1984, with a reduction of top marginal tax rates from 70 to 50 percent in 1982 and of other tax rates by 23 percent in three annual steps. Further, the income threshold for the top rate substantially increased from $\$ 85,600$ in 1982 to $\$ 109,400$ (1983) and $\$ 162,400$ (1984) for married couples filing jointly. Similar threshold increases occurred for cou-

\footnotetext{
${ }^{17}$ For more information on TAXSIM see Feenberg and Coutts (1993) or visit http://www.nber.org/taxsim/.
} 
ples filing separately and singles. The reduction in tax revenue amounting to 2.89 percent of GDP (four year average) was substantially larger than for RA78.

The motivation of TRA86 was to make the tax system simpler and more conducive to long-run growth (Auerbach and Slemrod 1997 and Romer and Romer 2009). Key aspects of the reform were the broadening of the tax base and reductions in marginal tax rates. Consequently, the reform was almost revenue neutral. TRA86 further lowered the top marginal rate to 38.5 percent in 1987 and to 28 percent in 1988 , reduced the number of tax brackets from 15 in 1986 to four in 1988, but also substantially expanded the EITC with financial benefits for low-income households.

Reforms in the 1990s which had considerable direct policy effects are OBRA90, OBRA93 and TRA97. OBRA90 contained increases in income taxes as well as expansions of the EITC and other low-income credits. Further, payroll taxes were increased by lifting the taxable maximum for Hospital Insurance which were finally abolished in 1994. OBRA93 then led to the largest single expansion of the EITC (cf. Eissa and Hoynes 2011), and further increases in income tax rates were implemented, e.g. the top rate rose from 31 to 39.6 percent in 1993. The EITC became much more generous in 1994 with higher maximum credits and an expansion to single workers with no children. These EITC expansions continued in the next years. The revenue effect of OBRA90 and OBRA93 was - again evaluated on a four year average - positive and amounted to 0.5 and 0.63 percent of GDP, respectively. TRA97 lowered capital gains tax rates and introduced additional tax credits (child and education tax credits).

EGTRRA01 and JGTRRA03 were characterized by reductions in marginal tax rates, both for low- and high-income families, expansions of the child tax credits, and reductions in taxes on dividends. In 2003, JGTRRA accelerated those provisions of EGTRRA which were not set to become effective until 2006. Both reforms had a revenue-decreasing effect ( -0.71 and -0.57 percent of GDP, 4 year average).

Finally, ARRA09 was a countercyclical fiscal stimulus program in response to the severe economic contraction in 2008/2009. It contained, among other measures, individual tax cuts and adjustments of the Alternative Minimum Tax (AMT) which, together with some business tax incentives, accounted for $\$ 263.3$ billion of the total $\$ 787$ billion program at the end of December 2009 (see e.g. Council of Economic Advisors 2010a). Important tax measures were the creation of the Making Work Pay Credit, a refundable tax credit of up to $\$ 400$ for working individuals and up to $\$ 800$ for married taxpayers filing jointly, the American Opportunity Tax Credit, EITC expansions and an extension of the AMT relief to 2009 as well as an increase in the AMT tax exemption (Council of Economic Advisors 2010b, Tax Policy Center 2011). 


\section{Results}

\subsection{Trends in average tax rates and income inequality}

Before we turn to the decomposition analysis, we first describe the general trend in average tax rates and income inequality during the observation period. For the calculation of average tax rates, we group households by quintiles of market income and calculate the share of income paid in federal and state level income taxes. ${ }^{18} \mathrm{We}$ account for tax expenditure on the federal and state level. Results are reported in Figure 1. Compared with the average tax rates for households at the top and the bottom of the income distribution, those for the second to fourth income quintile show less variation and are combined in one series. The average tax rate for the highest quintile decreased from a peak in 1981 (almost 30 percent) until reaching the trough in 1990 (23 percent). It constantly increased in the 1990s reaching again the 30 percent level in 2000 before it started to fall in the following years. Contrary, the average tax rate for households in the lowest income quintile was almost constant until 1990 and turned negative afterwards. It decreased dramatically in the period from 1990 to 1996 due to expansions of the EITC. After a slight increase in the second half of the 1990s, it fell again after 2000. Marked changes in average tax rates occured especially during the Great Recession period of 2008/2009. While the average tax rate for the lowest quintile increased sharply in 2008, the drop in 2009 was even larger. The increase in 2008 was due to the substantial decline in market income of households at the bottom of the distribution (see also Figure 2) which was caused by an unprecedented rise in the unemployment rate. In fact, this trend continued in 2009 with the unemployment rate reaching a peak of 10.1 percent in October 2009 (U.S. Department of Labor. Bureau of Labor Statistics 2010), but at the same time, discretionary policy measures enacted through ARRA09 (cf. section 3.4 and Table 1) became effective and led to a sharp decline in tax liabilities, particularly for low income households (Council of Economic Advisors 2010b).

Income inequality in the United States has increased dramatically over the past 30 years. For instance, for households headed by working-age individuals, market incomes in the upper part of the distribution show an upwards trend in almost all periods since 1978, while they increased remarkably little in the middle and show large and sustained declines at the bottom during and after recessions (cf. Figure 2). This is particularly true for the recent economic crisis.

The following analysis is essentially based on three percentile ratios which capture different parts of the income distribution (90/10, 90/50 and 50/10) and spans the period from 1978 to 2009. Importantly, we now focus on pre- and post-tax income

\footnotetext{
${ }^{18}$ Cf. Piketty and Saez (2007) who also rank families by market income, but focus on federal taxes. Contrary, estimates for average tax rates of the Congressional Budget Office (2010) are based on comprehensive household income including cash transfers and in-kind benefits.
} 
instead of on market income (cf. section 3.3). We first describe the overall trend in pre-tax inequality. Figure 3 reports the percentile ratios at each point in time while Figures 4-7 show the absolute change relative to the starting year 1978 (black dots). The 90/10 ratio for household pre-tax incomes increases by roughly 3.2 points (from 6.1 to 9.3 , or by 52 percent) over the period as a whole. The upper and lower half of the distribution equally contribute to this increase. In line with other studies on inequality trends, the increase was particularly steep until the early-mid 1990s (see section 2). The gap between the 90th and the 10th percentiles then dropped until 2000 before rising again at a reduced pace in the years before the Great Recession and accelerating during the 2008-2009 period (cf. Burkhauser and Larrimore 2011).

Post-tax inequality series closely follow the pre-tax series, but with some differences between the three ratios as is illustrated in Figures 4-7. The dark triangles show the difference between the series for pre- and post tax inequality (i.e. the line "measured redistribution" gives the differential between pre-tax inequality in period $t$ relative to its base year value in 1978 and post-tax inequality in $t$ relative to the base year). Although there are some fluctuations, the overall picture is one of a rather constant (in case of 90/10 and 50/10 ratio) or slightly decreasing (90/50) difference in preand post-tax inequality in the 1980s. Beginning in the early 1990s, however, the difference started to increase for all three measures until reaching a peak in the late 1990s (90/10 and 50/10 ratio) or the early 2000s (90/50 ratio). After a slight reduction, all three series remained constant until the mid 2000s. This development is in line with previous research, see e.g. Heathcote et al. (2010) who report similar trends for the Gini coefficient. During the Great Recession period, post-tax inequality increased significantly in 2008, whereas part of this increase was reversed in 2009 due to the tax cuts enacted through ARRA09.

The fact that the difference between pre- and post-tax income inequality largely remained constant during the 1980s and became larger in certain periods (in particular during 1989-1994 for the 90/10 and 50/10 ratio and until the early 2000s for the 90/50) shows that the overall redistributive capacity of the U.S. income tax system significantly rose during these periods (see e.g. Heathcote et al. 2010). However, it can be suspected that this increased redistributive effect was driven by the very pronounced increase in pre-tax inequality over time. Clearly, actual policy effects and the indirect role of pre-tax income changes cannot be disentangled with a simple comparison of preand post-tax inequality. As explained in our methodology section, the decomposition analysis that follows allows us to separate both effects by controlling for the underlying pre-tax income distribution. 


\subsection{Decomposition results}

We first illustrate the decomposition procedure with Tables 2-4. In each of these tables, we compare two years, i.e., before and after important legislation changes have been enacted (base and end year). We decompose the total change in post-tax inequality into two components. The first is due to tax policy reforms (tax policy effect) while the second is due to changes in the underlying data ("other" effect). Precisely, the latter effect accounts for changes in the distribution of market income (labor or capital income), in the population (participation rates, household structure which affects equivalence scales) and in replacement incomes which are included in pre-tax income (e.g. unemployment benefits or welfare payments). For instance, Table 2 analyzes changes in inequality which occurred between the base year 1978 - the year when the RA78 reform was enacted - and year 1980 when it was fully phased-in. The left part of the table reports the different components of the decomposition as detailed in section 3 , including base and end period scenarios $((0) /(1)$ and (4) respectively) as well as all the relevant counterfactuals (scenario (2) answers the question how large inequality would have been, had the tax system of 1978 been in place in 1980; (3) is the counterfactual scenario of the 1980 tax system being in place in 1978). The column labeled "(4)-(0)" shows the total change in inequality over time. The right part of the Table reports both the policy and "other" effect for decompositions I, II and the Shapley-value approach.

The other effect. To understand the decomposition results, we start with the "other" effect which is shown in the last column of Tables 2-4 for the Shapley-value decomposition. A substantial part of the increase in post-tax income inequality which can be observed in those periods during which the large tax reforms were phased-in was due to changes in the pre-tax income distribution. For example, the 90/10 ratio would have increased by 0.28 points from 1978 to 1980 if no tax policy change had occurred (cf. Table 2 for the years 1978-1980). The sign of the inequality change due to the other effect is also positive for the reform periods 1981-1984 and 1986-1988. This partly captures income shifting from the corporate to the individual sector, especially after TRA86 (see e.g. Feenberg and Poterba 1993 and Slemrod 1996). The other effect is even more pronounced for some of the following reform periods, especially for the period from 1989 to 1994 which was characterized by a steep increase in inequality (see last section). In this period, the 90/10 ratio of post-tax income would have increased by 0.54 points - a larger effect as was actually observed (cf. Table 4 for the period 1989-1994) - in the absence of any changes in tax policy.

The direct policy effect. Following a chronological order, we start with RA78 to assess the effect of legislative changes in tax policy on post-tax income inequality. As can be seen from the Shapley-value policy effect, RA78 counteracted the trend of 
growing inequality. However, the inequality-decreasing effect of tax policy was not large enough to offset the overall trend of growing inequality. The tax policy effect led to a reduction in all inequality measures considered in our analysis. Results for decompositions I and II yield almost identical effects. ${ }^{19}$

A different picture emerges for the two large tax reforms in the 1980s. The effect of ERTA81 was to exacerbate the trend of growing inequality over the years 1981-1984, with 35-50 percent of the increase in post-tax inequality - depending on the chosen inequality measure - due to the reform (i.e. the tax-policy effect divided by the total change in post-tax inequality).

Contrary to ERTA81, TRA86 certainly contained both inequality-increasing (reduction in top marginal tax rates) and -decreasing elements (expansion of EITC, tax base broadening). This can be seen in the last two columns of Table 3 (1986-1988). The policy effect of TRA86 led to a slight decrease (increase) in inequality at the bottom (top) of the distribution (50/10 and 90/50 ratio). Interestingly, the inequalityincreasing effect of TRA86 on the Gini coefficient as well as the 90/10 and 90/50 ratios was even larger than the increase due to changes in the pre-tax income distribution. The contribution of tax policy to the growing post-tax inequality ranges between $67-76$ percent for this period.

The period in the early 1990s was then characterized by steep increases in pre- and post-tax income inequality. OBRA90 and OBRA93 counteracted - at least to some extent - the rapidly growing inequality at that time. Comparing the years 1989 and 1994, i.e. the year before OBRA90 was enacted with the year when OBRA93 was effective (cf. Table 4, 1989-1994), one can conclude that the overall effect of these reforms was inequality-decreasing, especially in the lower half of the distribution due to large expansions of the EITC. The tax policy effect worked in the opposite direction as changes in the pre-tax income distribution and made up 75 percent of the other effect for the lower part of the distribution, whereas it was negligible for the upper part of the distribution.

Finally, we show in the lower part of Table 4 (2000-2004) that the effect of EGTRRA01 and JGTRRA03 was to increase inequality, in particular in the middle and at the top of the distribution through reductions in marginal tax rates. However, overall the policy effect was moderate compared with the increase in inequality due to changes in the pre-tax income distribution and accounted for up to 22.2 percent of the total increase in post-tax inequality. An overall assessment of the policy effect of ARRA09 is not possible yet as its measures extend to 2010 for which no data are available at the time of writing of this paper. However, its impact on average tax rates is discussed in the

\footnotetext{
${ }^{19}$ The comparison of columns (4) and (2) of Table 2 (1978-1980) reveals that, without RA78, inequality in 1980 would have been higher as it actually was in that year. The second counterfactual reported in this table is shown in column (3). If the tax system of 1980 had been in place in 1978, inequality would have been lower compared with the observed inequality in 1978 (compare columns (3) and (1)).
} 
following section.

Policy effect on average tax rates. Average tax rates are influenced by changes in tax policy and the distribution of pre-tax income in the same way as the inequality measures discussed above. Hence, we isolate the policy effect and report the (cumulative) hypothetical change in average tax rates (in percentage points) if the pre-tax income distribution would have remained constant during the whole observation period in Figure 9. Strikingly, in the 1980s the policy effect on average tax rates was strongest for households in the highest income quintile. Taken together, ERTA81 and TRA86 (time period 1981-1988) reduced average tax rates by 10 percentage points for the fifth quintile, by 6 percentage points for the fourth quintile, by 4 percentage points for the third quintile, but only by 1 (3) points for the second (first) quintile. The EITC reforms starting with OBRA90 and OBRA93 led to considerable reductions in average tax rates for low income households while tax reforms in the early 2000s further reduced average tax rates at the top of the distribution. Tax changes implemented through ARRA09, e.g. extensions of existing tax credits (EITC) and the implementation of new credits (Making Work Pay Credit), further reduced average tax rates, in particular at the bottom of the distribution.

Year-to-year analysis. We have replicated the decomposition analysis for all years in the data and report the results in Figures 10-13. In these graphs, policy and "other" effects are presented as percent of post-tax income inequality of the previous year. The total effect, which is simply the sum of both effects, is the percentage change between two consecutive years. Confirming the results presented above for specific policy events, these graphs demonstrate that the policy effect was usually smaller than the other effect in years where policy reforms occurred (and obviously zero in years with no or minor changes in the tax schedule). In certain periods, tax policies actually aggravated the increase in pre-tax income inequality, while they were more "countercyclical" in other times. The former was particularly true for the 1980s when the tax cuts of ERTA81 and TRA86 became effective (the policy effect actually outweighed the "other" effect in 1983 for $90 / 10$ and 90/50 and in 1987 for 90/10). This was also the case, for the 90/10 and 50/10 ratios, in some of the years after 1993 when pre-tax income inequality went down and tax-policy enforced this trend. The latter - an inequality-reducing effect - was pronounced in the late 1970s (RA78), in the period 1990-1993 (OBRA90 and OBRA93), mainly due to expansions of the EITC, as well as in 2009 (ARRA09).

Figure 14 extracts the policy effect (again relative to the inequality measure of the previous year) for all three percentile ratios. It confirms that the different parts of the distribution were affected simultaneously, with some exceptions. In particular, the 90/50 ratio showed very little response to the policy changes in the 1990s. This reflects the fact that EITC extensions concerned more the lower incomes. 
Comparison to the literature. There is no comparable study which covers such a long time period in a consistent framework as we do. Previous research has been partial in the sense that it focused on one policy event or a much shorter time period. Gramlich et al. (1993) and Poterba (2007) who discuss the relative size of the policy effect relative to the changes in the pre-tax income distribution, are the studies closest to ours. First, it must be stressed that a comparison with these studies has to be handled with some caution given the differences with respect to simulated policies, inequality measures, income concepts and data used. Nevertheless, the policy analyst might gain some insight about the quantitative impact of tax policy on income inequality. Gramlich et al. (1993) find that 16 percent of the increase in the Gini-coefficient in the 1980s was due to changes in policies, yet it seems these authors account for a broader policy effect that includes transfers. ${ }^{20}$ When focusing on changes in the tax system only, we find a contribution of the policy effect of 37 percent to the total change in the Gini. ${ }^{21}$ This implies that changes in transfer policies to some extent counteracted the increase in inequality in that period. Similarly, Poterba (2007) calculates counterfactuals for the years 2000 and 2004. While focusing on top incomes, the author also reports changes for different quintiles. Poterba (2007) concludes that policy changes had a very minor effect compared to changes in pre-tax income inequality, which is totally in line with our results (see Table 4).

Comparing effects over time. Finally, we reconsider the questions of - first - how the overall redistributive capacity of the income tax system has changed and - second how reforms over the whole period 1978-2009 have affected income inequality in total. Therefore, we go back to Figures 4, 6 and 7 and focus on measured redistribution (dark triangles) and the pure policy effect (hollow triangles). For the interpretation of the pure policy effect in Figures 4, 6 and 7, it is important to note that the hollow triangles in each year $t$ show the cumulative policy effect from starting year 1978 to year $t$. As discussed in the introduction and shown in many contributions since Musgrave and Thin (1948), in a progressive tax system, one would expect a co-movement of tax redistribution (dark triangles) and income inequality before taxes. In other words, given no changes in the tax system between two periods, a progressive tax system cushions changes in pre-tax inequality such that the change in post-tax inequality is less pronounced. ${ }^{22}$ In Figure 4, such a link is indeed apparent during periods when in-

\footnotetext{
${ }^{20}$ Gramlich et al. (1993) argue that with policy parameters of 1980 still in place in 1990, the posttax Gini in 1990 would have increased by only 0.057 points instead of by 0.068 points as it actually did, i.e. the policy change accounted for 16 percent of the Gini increase.

${ }^{21}$ Following the same line of arguing as Gramlich et al. (1993), we find that with tax policy parameters of 1980 still in place in 1990, the Gini coefficient would have increased by 0.0303 points instead of the observed rise by 0.0481 points. Thus, according to our calculations, 63 percent of the increase were due to changes in the pre-tax income distribution and 37 percent due to tax policy.

${ }^{22}$ This property of a progressive tax system is also known as automatic stabilization (see, e.g., Auerbach and Feenberg 2000 or Dolls et al. 2010). Contrary, with a regressive system the change in
} 
come gaps widened rapidly (1980-1982, 1989-1993 and 2009) or narrowed (late 1990s). Importantly, a comparison with the pure policy effect conveys that this "automatic" increase in redistribution has been the main (and sometimes the only) reason for the tax system to slow down the growth in post-tax inequality. Policy changes implemented in 1982, 1987 and the early 2000s were disequalizing, while the reforms of the late 1970s, early 1990s and 2009 made income taxes more redistributive. Over the time period as a whole, these direct effects of policy changes more or less canceled out. The results for the upper and lower parts of the distribution (Fig. 6 and 7) show that the equalizing effect of policy in the early-to-mid 1990s was a result of changes that improved the situation of low-income earners, notably the increased generosity of the EITC. By contrast, from 1982-1988, policy configurations exacerbated the income gaps in the upper part of the distribution (between the 90th and the 50th percentile), had the population and pre-tax distribution remained unchanged. The (only) reason why the tax system nevertheless compensated some of the growing pre-tax income disparities in the upper income segment is that the built-in progressivity made the tax system more redistributive as income inequalities grew - and this effect was stronger than the weakening of the redistributive effect produced by policy reforms.

Given the data quality issues discussed in section 3, there are good reasons for basing an analysis of longer-term trends on inequality measures that are not unduly influenced by measurement errors at the top (or the bottom) of the distribution. It is nevertheless interesting to compare the results of the decomposition of inter-quintile ratios, such as the P90/P10, with more comprehensive global inequality measures, such as the Gini coefficient. Figure 8 shows that the overall patterns are the same: a large increase in pre-tax income inequality, increased redistribution which compensates some of this disequalizing effect, and little contribution of policy changes over the period as a whole. The important difference, however, is that taxes on incomes were much less able to counter the increase in pre-tax inequality (both the policy effect and the total change in redistribution are close to zero and inequality therefore grew by about the same extent whether measured in pre- or in post-tax terms). The Gini coefficient measures income differentials in all parts of the distribution and, compared to the P90/P10 ratio, gives (much) more weight to income disparities in the middle. The fact that redistribution as measured by the Gini coefficient compensated for only about 10 percent of the increase in pre-tax inequality suggests that the tax system is less effective at countering changes in the middle (e.g., due to a "hollowing out" of the middle classes), than at either end of the distribution.

Political cycles and inequality changes. We have seen that tax policy indeed had an inequality-increasing effect in the 1980s and early 2000s and an inequality-

post-tax inequality would be larger, whereas changes in pre- and post-tax inequality would be equal with a proportional system. 
decreasing effect in the early 1990s and in 2009. These sub-periods can be broadly classified by Republican and Democrat administrations. Our counterfactual simulations also show that during Republican administrations average tax rates fell strongest for high income, but very little for low income households (Figure 9). This paper therefore complements analyses conducted by Bartels (2008) as the decomposition analysis enables us to control for changes in the pre-tax income distribution and hence to single out the pure policy effect. Bartels (2008) finds that under Democratic presidents real incomes grew much faster at the bottom and in the middle of the income distribution compared to Republican Administrations. He further shows that income growth was also much more equally distributed under Democratic presidents than under Republicans, where incomes of the rich increased by far the most. These findings are also visible in Figures 2-8 where increases in inequality by and large coincide with Republican presidents. This confirms the view by Krugman (2005) that partisan politics have a major impact on the income distribution. This is true not only for pre-tax but also for post-tax incomes.

\subsection{Robustness checks}

Choice of the uprating factor. An interesting question is to what extent our results depend on the choice of the uprating factor. As a sensitivity check, we replicate the analysis for the period 1986-1988 with mean nominal wage growth as uprating factor. ${ }^{23}$ The period after TRA86 is appropriate for a robustness check for two reasons. First, the growth rates of mean nominal wages from 1986 to 1988 exceeded those of the CPI by 74 and 21 percent (6.38 vs. 3.66 percent and 4.93 vs. 4.08 percent), respectively. This was one of the largest differences between the two indices in the observation period which makes the choice of the uprating factor a critical decision. Second, income brackets were adjusted due to changes in tax rates, but not due to indexation. From 1986 to 1987 (1987 to 1988), the number of tax brackets fell from 15 to 5 (5 to 4), see Table 1.

Results do not change much with nominal wage indexation as can be seen in Table 3 (lower part). The policy effect is slightly smaller for the Gini and P90/P10 and identical for the other two percentile ratios. Because of the larger growth rates, 'fiscal drag' in the counterfactual scenarios (2) and (3) is stronger for wage than for price indexation as the propensity that taxpayers near the top-end of a tax bracket move in the upper bracket is higher. Hence, the inequality-increasing effect of TRA86 is marginally cushioned when uprating with wage growth.

\footnotetext{
${ }^{23}$ We choose the National Average Wage Index according to which the taxable maximum for Social Security is automatically adjusted. See http://www.ssa.gov/OACT/COLA/AWI.html for further information.
} 
Itemized deductions. As the CPS lacks information with regard to itemized deductions, we impute them from tax return data compiled by the Statistics of Income (SOI) division of the IRS. The imputation procedure is based on Alm et al. (2005) and consists of two steps. First, we calculate for each year and income group the share of taxpayers who itemize by building 14 income groups in the SOI data based on adjusted gross income (AGI). We follow Alm et al. (2005) and assume that there are no itemizers with incomes below $\$ 10,000$. Corresponding income groups are constructed in the CPS and taxpayers are randomly drawn such that the shares of itemizers per income group match between SOI and CPS data. Second, the amount of itemized deductions is imputed by calculating itemized deductions as a share of federal AGI in the SOI data and by multiplying this share with the federal AGI of those who itemize in the CPS. With this adjustment, we rerun all our calculations.

An important result of this sensitivity check is that post-tax inequality slightly increases. The reason is that the share of itemizers increases by income group, i.e. it is more likely for taxpayers with high incomes to have itemized deductions exceeding the standard deduction. As a consequence, the measured redistribution mechanically decreases as can be seen in Figure $5 .^{24}$ The tax policy effect for specific reform periods, however, changes only marginally (if at all) when itemized deductions are imputed. An exception is the period 1986-1988 in which the share of itemizers decreased. This was due to TRA 86 which led to an increase of the standard deduction and a cut of certain itemized deductions (see Table 1 and Auten et al. 1992) limiting to some extent the inequality-increasing effect of TRA86.

Income concept. Our measure of pre-tax income includes government transfers, e.g. income from welfare (Aid to Families with Dependent Children, AFDC / Temporary Assistance for Needy Families, TANF), unemployment benefits as well as Supplemental Security Income (SSI). Alternatively, we have calculated a variant which excludes transfers from the pre-tax income measure. In this variant, pre-tax income is equal to market income which leads to an increase in pre-tax inequality as well as measured redistribution. The reason is that in this case the difference between pre- and post-tax income includes taxes and transfers. The tax policy effect, however, is unaffected by the change in the definition of pre-tax income. ${ }^{25}$

\footnotetext{
${ }^{24}$ We only report results for the P90/P10 ratio due to space restrictions. Results for other inequality measures as well as shares of itemizers and itemized deductions relative to adjusted gross income per income group are available from the authors upon request. The series in Figure 5 excludes all years after 2006 as we do not have access to SOI data for more recent years.

${ }^{25}$ It would be interesting to conduct additional simulations of different transfer policies in order to single out the joint policy effect of taxes and transfers. However, this would require strong assumptions mainly with regard to eligibility when conducting policy swaps as there is only limited information in the CPS data. Therefore, this paper focuses on the redistributive role of tax policy.
} 
Sample selection. We additionally check if our results are sensitive to the sample selection and recalculate the analysis for the full CPS sample instead of focusing on the working-age population. The inequality measures and thus the other effect slightly deviate from our baseline results, but importantly, the policy effect is hardly affected. ${ }^{26}$ The robustness checks thus reinforce that our results and, in particular the tax policy effect, are not sensitive to the choice of the uprating factor, the imputation of itemized deductions, the income concept and the sample selection.

\section{Conclusion}

A question of particular policy relevance is to what extent observed changes in income inequality can be attributed to direct policy action or to other factors that are less easily influenced by policy-makers. For any given household, the tax burden has a direct impact on the resources available for consumption. However, the assessment of trends in the redistributive properties of tax policies is complicated by the fact that pre-tax incomes and the population change at the same time as policy parameters. Since tax burdens depend on both incomes and population characteristics, a given tax system can become more or less effective at reducing inequalities, even if policy rules remain unchanged.

In this paper, we have asked how tax policy has affected post-tax income inequality in the U.S. from 1978 to 2009. For this purpose, we have conducted a set of comprehensive counterfactual simulations by applying - on a yearly basis - tax policy parameters of a certain base year to the pre-tax income distribution of the end year and vice versa. The decomposition analysis has enabled us to quantify the direct effect of tax policy on the post-tax income distribution. A main finding of this paper is that the measured redistribution increased over the whole time period, but this was mainly due to the pronounced increase in pre-tax inequality. The direct effects of policy changes almost canceled out. Focusing on selected time periods, we find that tax policy indeed had an inequality-increasing effect in the 1980s and early 2000s and an inequality-decreasing effect in the early 1990s and in 2009. These sub-periods can be broadly classified by Republican and Democrat administrations with disequalizing effects observed for the former and equalizing effects for the latter.

Throughout this paper, we have focused on the direct policy effect and have neglected behavioral responses to tax policy. This is done on purpose in order to isolate the pure policy effect - the effect which is controlled by the policy-maker. In future research, it would be interesting to separate the residual effect into the indirect, behavioral policy effect and a population effect. However, we argue that the latter is more important in the long-run than for the year-to-year analysis that we have conducted

\footnotetext{
${ }^{26}$ Results are available from the authors upon request.
} 
here. Moreover, it would be interesting to further analyze the political economy of partisan tax politics.

Against the background of a sharp increase in inequality resulting from the Great Recession and in light of the recently reached budget deal between Democrats and Republicans, one crucial question is which groups of American society will have to bear the fiscal burden of the budget cuts in the next few years. The tax cuts enacted in the early 2000s had an inequality-increasing effect (e.g., without the tax reforms of 2001 and 2003, inequality would have increased by a quarter less). Therefore, we argue that an expiration of the 2001/2003 tax cuts at the end of 2012 would have beneficial effects, not only due to increased tax revenue and a strengthening of automatic stabilizers which are rather weak in the U.S. compared to European countries (Dolls et al. 2010) - but also with regard to a reduction in inequality. 


\section{References}

Alm, J., Lee, F. and Wallace, S. (2005). How fair? Changes in federal income taxation and the distribution of income, 1978 to 1998, Journal of Policy Analysis and Management 24 (1): 5-22.

Atkinson, A., Rainwater, L. and Smeeding, T. (1995). Income distribution in OECD countries. Evidence from the Luxembourg Income Study, Social Policy Studies No. 18, Organization for Economic Cooperation and Development, Paris.

Auerbach, A. and Feenberg, D. (2000). The significance of federal taxes as automatic stabilizers, Journal of Economic Perspectives 14: 37-56.

Auerbach, A. and Slemrod, J. (1997). The Economic Effects of the Tax Reform Act of 1986, Journal of Economic Literature XXXV: 589-632.

Auten, G., Cilke, J. and Randolph, W. (1992). The effects of tax reform on charitable contributions, National Tax Journal 45 (3): 267-290.

Autor, D., Katz, L. and Kearney, M. (2008). Trends in U.S. wage inequality: Revising the revisionists, Review of Economics and Statistics 90 (2): 300-323.

Bakija, J., Cole, A. and Heim, B. (2010). Jobs and income growth of top earners and the causes of changing income inequality: Evidence from U.S. tax return data, Working paper, Williams College.

Bargain, O. and Callan, T. (2010). Analysing the effects of tax-benefit reforms on income distribution: A Decomposition Approach, Journal of Economic Inequality 8 (1): 1-21.

Bartels, L. (2008). Unequal Democracy - The Political Economy of the New Gilded Age, Princeton University Press.

Bishop, J., Chow, K., Formby, J. and Ho, C. (1997). Did tax reform reduce actual US progressivity? Evidence from the Taxpayer Compliance Measurement Program, International Tax and Public Finance 4: 177-197.

Bourguignon, F. and Spadaro, A. (2006). Microsimulation as a tool for evaluating redistribution policies, Journal of Economic Inequality 4(1): 77-106.

Burkhauser, R., Feng, S. and Jenkins, S. (2009). Using the P90/P10 ratio to measure U.S. inequality trends with Current Population Survey data: A view from inside the Census Bureau Vaults, Review of Income and Wealth 55 (1): 166-185. 
Burkhauser, R., Feng, S., Jenkins, S. and Larrimore, J. (2011a). Recent trends in top income shares in the USA: Reconciling estimates from March CPS and IRS tax return data, Review of Economics and Statistics forthcoming.

Burkhauser, R., Feng, S., Jenkins, S. and Larrimore, J. (2011b). Trends in United States Income Inequality Using the March Current Population Survey: The Importance of Controlling for Censoring, Journal of Economic Inequality forthcoming.

Burkhauser, R., Feng, S. and Larrimore, J. (2010). Improving imputations of top incomes in the public-use current population survey by using both cell-means and variances, Economics Letters 108 (1): 69-72.

Burkhauser, R. and Larrimore, J. (2011). How changes in employment, earnings, and public transfers make the first two years of the Great Recession (2007-2009) different from previous recessions \& why it matters for longer term trends, Russell Sage Foundation US2010 Project Research Report.

Burtless, G. (1999). Effects of growing wage disparities and changing family composition on the US income distribution, European Economic Review 43: 853-865.

Card, D. and DiNardo, J. (2002). Skill-biased technological change and rising wage inequality: Some problems and puzzles, Journal of Labor Economics 20: 733-783.

Clark, T. and Leicester, A. (2004). Inequality and two decades of British tax and benefit reform, Fiscal Studies 25 (2): 129-158.

Congressional Budget Office (2010). Average federal tax rates and income, by income category, 1979-2007, Accessed at http://www.cbo.gov/publications/collections/collections.cfm?collect=13.

Council of Economic Advisors (2010a). The Economic Impact of the American Recovery and Reinvestment Act of 2010, Second Quarterly Report.

Council of Economic Advisors (2010b). The Economic Impact of the American Recovery and Reinvestment Act of 2010, Third Quarterly Report.

Daly, M. and Valletta, R. (2006). Inequality and poverty in United States: The effects of rising dispersion of men's earnings and changing family behaviour, Economica 73: $75-98$.

Dardanoni, V. and Lambert, P. (2002). Progressivity comparisons, Journal of Public Economics 86: 99-122.

DeBacker, J., Heim, B., Panousi, V. and Vidangos, I. (2010). Rising inequality: Transitory or Permanent? New evidence form a panel of U.S. tax returns 1987-2006, Available at SSRN: http://ssrn.com/abstract $=1747849$. 
Dolls, M., Fuest, C. and Peichl, A. (2010). Automatic Stabilizers and Economic Crisis: US vs. Europe, NBER Working Paper 16275.

Eissa, N. and Hoynes, H. (2006). Behavioral Responses to Taxes: Lessons from the EITC and Labor Supply, in Tax Policy and the Economy 20, M.I.T. Press, 74-110.

Eissa, N. and Hoynes, H. (2011). Redistribution and Tax Expenditures: The Earned Income Tax Credit, National Tax Journal 64 (2): 689-730.

Feenberg, D. and Poterba, J. (1993). Income inequality and the incomes of very highincome taxpayers: Evidence from tax returns, in Tax Policy and the Economy 7, edited by James M. Poterba, M.I.T. Press, 145-177.

Feenberg, D. R. and Coutts, E. (1993). An Introduction to the TAXSIM Model, Journal of Policy Analysis and Management 12(1): 189-194.

Feldstein, M. (1995). The effect of marginal tax rates on taxable income: a panel study of the 1986 Tax Reform Act, Journal of Political Economy 103 (3): 551-572.

Gottschalk, P. and Danziger, S. (2005). Inequality of wage rates, earnings and family income in the United States, 1975-2002, Review of Income and Wealth 51 (2): 231254.

Gottschalk, P. and Smeeding, T. (1997). Cross-national comparisons of earnings and income inequality, Journal of Economic Literature 35: 633-87.

Gramlich, E., Kasten, R. and Sammartino, F. (1993). Growing inequality in the 1980s: The role of federal taxes and cash transfers, In Uneven tides: Rising inequality in America, ed. Sheldon Danziger and Peter Gottschalk, 225-49. New York: Russell Sage Foundation.

Gruber, J. and Saez, E. (2002). The elasticity of taxable income: evidence and implications, Journal of Public Economics 84: 1-32.

Heathcote, J., Perri, F. and Violante, G. (2010). Unequal we stand: An empirical analysis of economic inequality in the United States, 1967-2006, Review of Economic Dynamics 13 (1): 15-51.

Hotz, V. J. and Scholz, J. K. (2003). The Earned Income Tax Credit, In Moffitt, R. A. (ed.), Means-Tested Transfer Programs in the United States, 141-198. University of Chicago Press, Chicago, IL.

Immervoll, H. (2005). Falling up the stairs. An exploration of the effects of "bracket creep" on household incomes, Review of Income and Wealth 51 (1): 37-62. 
Kasten, R., Sammartino, F. and Toder, E. (1994). Trends in federal tax progressivity, 1980-93, In Tax progressivity and income inequality, ed. J. Slemrod, 9-50. Cambridge: Cambridge University Press.

Krugman, P. (2005). Losing Our Country, New York Times, June 10, 2005, A21.

Lambert, P. and Thoresen, T. (2009). Base independence in the analysis of tax policy effects: with an application to Norway 1992-2004, International Tax and Public Finance 16: 219-252.

Larrimore, J. (2010). Accounting for United States income inequality trends (19752009): The changing importance of male and female labor earnings inequality, Mimeo.

Larrimore, J., Burkhauser, R., Feng, S. and Zayatz, L. (2008). Consistent Cell Means for Topcoded Incomes in the Public Use March CPS (1976-2007), Journal of Economic and Social Measurement 33 (2-3): 89-128.

Leigh, A. (2008). Do redistributive state taxes reduce inequality?, National Tax Journal 61 (1): 81-104.

Lindert, P. (2000). Three centuries of inequality in Britain and America, Handbook of Income Distribution 1: 167-216.

Meyer, B. (2010). The effects of the Earned Income Tax Credit and recent reforms, in Tax Policy and the Economy 24, edited by Jeffrey Brown, M.I.T. Press, 153-180.

Meyer, B. and Sullivan, J. (2010). Consumption and income inequality in the U.S. since the 1960s, Working paper, University of Notre Dame.

Meyer, B. and Sullivan, J. (2011). Consumption and income poverty over the business cycle, Research in Labor Economics 32: 51-82.

Mitrusi, A. and Poterba, J. (2000). The Distribution of Payroll and Income Tax Burdens, 1979-99, National Tax Journal 53 (3): 765-794.

Musgrave, R. and Thin, T. (1948). Income tax progression, 1929-1948, Journal of Political Economy 56: 498-514.

OECD (2008). Growing Unequal? Income Distribution and Poverty in OECD Countries.

Piketty, T. and Saez, E. (2003). Income Inequality in the United States, 1913-1998, Quarterly Journal of Economics CXVIII (1): 1-39. 
Piketty, T. and Saez, E. (2007). How Progressive is the U.S. Federal Tax System? A Historical and International Perspective, Journal of Economic Perspectives 21 (1): $3-24$.

Poterba, J. (2007). Income inequality and income taxation, Journal of Policy Modeling 29: $623-633$.

Romer, C. and Romer, D. (2009). A narrative analysis of postwar tax changes, http://www.aeaweb.org//articles.php?doi=10.1257/aer.100.3.763.

Saez, E. (2003). The effect of marginal tax rates on income: a panel study of 'bracket creep', Journal of Public Economics 87: 1231-1258.

Saez, E., Slemrod, J. and Giertz, S. (2011). The elasticity of taxable income with respect to marginal tax rates: A critical review, Journal of Economic Literature forthcoming.

Shorrocks, A. (1999). Decomposition Procedures for Distributional Analysis: A Unified Framework based on the Shapley Value, University of Essex and Institute for Fiscal Studies, Wivenhoe Park.

Slemrod, J. (1992). Taxation and inequality: A time-exposure perspective, in Tax Policy and the Economy 6, edited by James Poterba, M.I.T. Press, 105-127.

Slemrod, J. (1996). High-Income Families and the Tax Changes of the 1980s: The Anatomy of Behavioral Response, In Empirical Foundations of Household Taxation, ed. M. Feldstein and J. Poterba, 169-192. University of Chicago Press.

Sutherland, H., Hancock, R., Hills, J. and Zantomio, F. (2008). Keeping up or Falling behind? The Impact of Benefit and Tax Uprating on Incomes and Poverty, Fiscal Studies 29 (4): 467-498.

Tax Policy Center (2011). Summary of major enacted tax legislation from 1940-2009, Accessed at http://www.taxpolicycenter.org/.

Tempalski, J. (2006). Revenue effects of major tax bills, Office of Tax Analysis Working Paper 81.

U.S. Department of Labor. Bureau of Labor Statistics (2010). Issues in Labor Statistics. Sizing up the 2007-09 recession: comparing two key labor market indicators with earlier downturns.

U.S. Social Security Administration (2011). Social Security Tax Rates, Accessed at http://www.ssa.gov/OACT/COLA/cbb.html and http://www.ssa.gov/OACT/ProgData/taxRates.html. 
Table 1: Tax Legislation

\begin{tabular}{|c|c|c|c|c|c|c|}
\hline & 1978 & 1979 & 1980 & 1981 & 1982 & 1983 \\
\hline \multicolumn{7}{|l|}{ Income Tax } \\
\hline Number of tax brackets* & 26 & 16 & 16 & 16 & 13 & 14 \\
\hline Lowest individual income tax rate** & $14 \% * * *$ & $14 \% * * *$ & $14^{*} 0^{* * *}$ & $13.83 \% * * *$ & $12 \% \%^{* * *}$ & $11 \% * * *$ \\
\hline $\begin{array}{l}\text { Lowest individual income single tax } \\
\text { bracket }\end{array}$ & $\$ 2,200-\$ 2,700$ & $\$ 2,300-\$ 3,400$ & $\$ 2,300-\$ 3,400$ & $\$ 2,300-\$ 3,400$ & $\$ 2,300-\$ 3,400$ & $\$ 2,300-\$ 3,400$ \\
\hline $\begin{array}{l}\text { Lowest individual income joint tax } \\
\text { bracket }\end{array}$ & $\$ 3,200-\$ 4200$ & $\$ 3,400-\$ 5500$ & $\$ 3,400-\$ 5,500$ & $\$ 3,400-\$ 5,500$ & $\$ 3,400-\$ 5,500$ & $\$ 3,400-\$ 5,500$ \\
\hline $\begin{array}{l}\text { Other individual income tax brackets } \\
\text { (percent)*, } * * * *\end{array}$ & $\begin{array}{c}15,16,17,19,22,25 \\
28,32,36,39,42,45 \\
48,50,53,55,58,60 \\
62,64,66,68,69\end{array}$ & $\begin{array}{c}16,18,21,24,28 \\
3237,43,49,54 \\
59,64,68\end{array}$ & $\begin{array}{c}16,18,21,24,28,32 \\
37,43,49,54,59,64 \\
68\end{array}$ & $\begin{array}{c}16,18,21,24,28 \\
3237,43,49,54 \\
59,64,68\end{array}$ & $\begin{array}{l}14,16,19,22,25 \\
29,33,39,44,49\end{array}$ & $\begin{array}{c}13,15,17,19,23 \\
26,30,35,40,44, \\
48\end{array}$ \\
\hline $\begin{array}{l}\text { Highest individual income tax bracket } \\
\text { rate }\end{array}$ & $70 \%$ & $70 \%$ & $70 \%$ & $70 \%$ & $50 \%$ & $50 \%$ \\
\hline Rate on long-term capital gains & $\begin{array}{l}40 \% \text { of individual rate, } \\
\text { maximum } 39.875 \%\end{array}$ & $\begin{array}{l}40 \% \text { of individual } \\
\text { rate, maximum } 28 \%\end{array}$ & $\begin{array}{l}40 \% \text { of individual } \\
\text { rate, maximum } 28 \%\end{array}$ & $\begin{array}{l}40 \% \text { of individual } \\
\text { rate, maximum } 20 \%\end{array}$ & $\begin{array}{l}40 \% \text { of individual } \\
\text { rate, maximum } 20 \%\end{array}$ & $\begin{array}{l}40 \% \text { of individual } \\
\text { rate, maximum } 20 \%\end{array}$ \\
\hline Rate on dividends & $=$ individual rates & $=$ individual rates & $=$ individual rates & $=$ individual rates & $=$ individual rates & $=$ individual rates \\
\hline $\begin{array}{l}\text { Limitations on personal exemption and } \\
\text { itemized deductions }\end{array}$ & N.A. & N.A. & N.A. & N.A. & N.A. & N.A. \\
\hline Standard Deduction & $\begin{array}{c}\$ 2,200 \text { (single person) } \\
/ \$ 3,200 \text { (married } \\
\text { couple) }\end{array}$ & $\begin{array}{c}\$ 2,300 \text { (single } \\
\text { person) / } \$ 3,400 \\
\text { (married couple) }\end{array}$ & $\begin{array}{c}\$ 2,300 \text { (single person) } \\
/ \$ 3,400 \text { (married } \\
\text { couple) }\end{array}$ & $\begin{array}{c}\$ 2,300 \text { (single } \\
\text { person) / } \$ 3,400 \\
\text { (married couple) }\end{array}$ & $\begin{array}{c}\$ 2,300 \text { (single } \\
\text { person) / } \$ 3,400 \\
\text { (married couple) }\end{array}$ & $\begin{array}{c}\$ 2,300 \text { (single } \\
\text { person) } / \$ 3,400 \\
\text { (married couple) }\end{array}$ \\
\hline AMT exemption ${ }^{* * * * *}$ & $\begin{array}{l}\$ 20,000 \text { for joint and } \\
\text { single filers }\end{array}$ & $\begin{array}{l}\$ 20,000 \text { for joint } \\
\text { and single filers }\end{array}$ & $\begin{array}{l}\$ 20,000 \text { for joint and } \\
\text { single filers }\end{array}$ & $\begin{array}{l}\$ 20,000 \text { for joint } \\
\text { and single filers }\end{array}$ & $\begin{array}{l}\$ 30,000 \text { for single } \\
\text { filers, } \$ 40,000 \text { for } \\
\quad \text { joint filers }\end{array}$ & $\begin{array}{l}\$ 30,000 \text { for single } \\
\text { filers, } \$ 40,000 \text { for } \\
\quad \text { joint filers }\end{array}$ \\
\hline
\end{tabular}




\begin{tabular}{|c|c|c|c|c|c|c|}
\hline & 1978 & 1979 & 1980 & 1981 & 1982 & 1983 \\
\hline \multicolumn{7}{|l|}{ Tax credits } \\
\hline Child tax credit & N.A. & N.A. & N.A. & N.A. & N.A. & N.A. \\
\hline $\begin{array}{l}\text { Child and dependent care tax credit } \\
\text { (non-refundable) } \text { ( } * * * * *^{-}\end{array}$ & $\begin{array}{l}\$ 400 \text { for each of first } 2 \\
\text { dependents, maximum } \\
20 \% \text { of expenditures }\end{array}$ & $\begin{array}{l}\$ 400 \text { for each of } \\
\text { first } 2 \text { dependents, } \\
\text { maximum } 20 \% \text { of } \\
\text { expenditures }\end{array}$ & $\begin{array}{l}\$ 400 \text { for each of first } \\
2 \text { dependents, } \\
\text { maximum } 20 \% \text { of } \\
\text { expenditures }\end{array}$ & $\begin{array}{l}\text { Maximum } \\
\text { expenditure eligible } \\
\text { for credit is } \$ 2,400 \\
\text { for one child, } \\
\$ 4,800 \text { for two or } \\
\text { more; maximimum } \\
\text { credit is } 20 \%-30 \% \\
\text { of expenditures }\end{array}$ & $\begin{array}{l}\text { Maximum } \\
\text { expenditure eligible } \\
\text { for credit is } \$ 2,400 \\
\text { for one child, } \\
\$ 4,800 \text { for two or } \\
\text { more; maximimum } \\
\text { credit is } 20 \%-30 \% \\
\text { of expenditures }\end{array}$ & $\begin{array}{l}\text { Maximum } \\
\text { expenditure eligible } \\
\text { for credit is } \$ 2,400 \\
\text { for one child, } \\
\$ 4,800 \text { for two or } \\
\text { more; maximimum } \\
\text { credit is } 20 \%-30 \% \\
\text { of expenditures }\end{array}$ \\
\hline EITC rate and maximum credit & $10 \%, \max . \$ 400$ & $10 \%$, max. $\$ 500$ & $10 \%$, max. $\$ 500$ & $10 \%$, max. $\$ 500$ & $10 \%, \max . \$ 500$ & $10 \%$, max. $\$ 500$ \\
\hline EITC phaseout range and rate & $\begin{array}{l}\$ 6,000-\$ 10,000 \\
12.5 \%\end{array}$ & $\begin{array}{l}\$ 6,000-\$ 10,000 \\
12.5 \%\end{array}$ & $\begin{array}{l}\$ 6,000-\$ 10,000 \\
12.5 \%\end{array}$ & $\begin{array}{l}\$ 6,000-\$ 10,000 \\
12.5 \%\end{array}$ & $\begin{array}{l}\$ 6,000-\$ 10,000 \\
12.5 \%\end{array}$ & $\begin{array}{l}\$ 6,000-\$ 10,000, \\
12.5 \%\end{array}$ \\
\hline \multicolumn{7}{|l|}{ Social Security [a] } \\
\hline Social Security tax rate (OASDI) $[\mathrm{b}]$ & $10.1 \%$ & $10.16 \%$ & $10.16 \%$ & $10.7 \%$ & $10.8 \%$ & $10.8 \%$ \\
\hline Hospital Insurance tax rate $(\mathrm{HI})[\mathrm{c}]$ & $2.0 \%$ & $2.1 \%$ & $2.1 \%$ & $2.6 \%$ & $2.6 \%$ & $2.6 \%$ \\
\hline OASDI taxable maximum earnings & 17,700 & 22,900 & 25,900 & 29,700 & 32,400 & 35,700 \\
\hline HI taxable maximum earnings [d] & 17,700 & 22,900 & 25,900 & 29,700 & 32,400 & 35,700 \\
\hline
\end{tabular}

\begin{tabular}{|c|c|c|c|c|c|c|}
\hline & 1984 & 1985 & 1986 & 1987 & 1988 & 1989 \\
\hline \multicolumn{7}{|l|}{ Income Tax } \\
\hline Number of tax brackets* & 15 & 15 & 15 & 5 & 4 & 4 \\
\hline Lowest individual income tax rate** & $11 \%$ *** & $11 \% * * *$ & $11 \%$ *** & $11 \%$ & $15 \%$ & $15 \%$ \\
\hline $\begin{array}{l}\text { Lowest individual income single tax } \\
\text { bracket }\end{array}$ & $\$ 2,300-\$ 3,400$ & $\$ 2,390-\$ 3,540$ & $\$ 2,480-\$ 3,670$ & $\$ 0-\$ 1,800$ & $\$ 0-\$ 17,850$ & $\$ 0-\$ 18,550$ \\
\hline $\begin{array}{l}\text { Lowest individual income joint tax } \\
\text { bracket }\end{array}$ & $\$ 3,400-\$ 5,500$ & $\$ 3,540-\$ 5,720$ & $\$ 3,670-\$ 5,940$ & $\$ 0-\$ 3,000$ & $\$ 0-\$ 29,750$ & $\$ 0-\$ 30,950$ \\
\hline $\begin{array}{l}\text { Other individual income tax brackets } \\
\text { (percent)*, } * * * *\end{array}$ & $\begin{array}{c}12,14,16,18,22 \\
25,28,33,38,42 \\
45,49\end{array}$ & $\begin{array}{c}12,14,16,18,22 \\
25,28,33,38,42 \\
45,49\end{array}$ & $\begin{array}{c}12,14,16,18,22 \\
25,28,33,38,42 \\
45,49\end{array}$ & $15,28,35$ & 28,33 & 28,33 \\
\hline $\begin{array}{l}\text { Highest individual income tax bracket } \\
\text { rate }\end{array}$ & $50 \%$ & $50 \%$ & $50 \%$ & $38.5 \%$ & $28 \%$ & $28 \%$ \\
\hline Rate on long-term capital gains & $\begin{array}{l}40 \% \text { of individual } \\
\text { rate, maximum } \\
20 \%\end{array}$ & $\begin{array}{l}40 \% \text { of individual } \\
\text { rate, maximum } 20 \%\end{array}$ & $\begin{array}{l}40 \% \text { of individual } \\
\text { rate, maximum } \\
20 \%\end{array}$ & Ordinary rates & Ordinary rates & Ordinary rates \\
\hline Rate on dividends & $=$ individual rates & $=$ individual rates & $=$ individual rates & $=$ individual rates & $=$ individual rates & $=$ individual rates \\
\hline $\begin{array}{l}\text { Limitations on personal exemption and } \\
\text { itemized deductions }\end{array}$ & N.A. & N.A. & N.A. & N.A. & N.A. & N.A. \\
\hline Standard Deduction & $\begin{array}{c}\$ 2,300 \text { (single } \\
\text { person) / } \$ 3,400 \\
\text { (married couple) }\end{array}$ & $\begin{array}{l}\$ 2,400 \text { (single } \\
\text { person) } / \$ 3,550 \\
\text { (married couple) }\end{array}$ & $\begin{array}{c}\$ 2,480 \text { (single } \\
\text { person) / } \$ 3,670 \\
\text { (married couple) }\end{array}$ & $\begin{array}{c}\$ 2,540 \text { (single } \\
\text { person) } / \$ 3,760 \\
\text { (married couple) }\end{array}$ & $\begin{array}{c}\$ 3,000 \text { (single } \\
\text { person) } / \$ 5,000 \\
\text { (married couple) }\end{array}$ & $\begin{array}{c}\$ 3,100 \text { (single person) } \\
/ \$ 5,200 \text { (married } \\
\text { couple) }\end{array}$ \\
\hline AMT exemption $* * * * *$ & $\begin{array}{l}\$ 30,000 \text { for single } \\
\text { filers, } \$ 40,000 \text { for } \\
\text { joint filers }\end{array}$ & $\begin{array}{l}\$ 30,000 \text { for single } \\
\text { filers, } \$ 40,000 \text { for } \\
\text { joint filers }\end{array}$ & $\begin{array}{l}\$ 30,000 \text { for single } \\
\text { filers, } \$ 40,000 \text { for } \\
\text { joint filers }\end{array}$ & $\begin{array}{l}\$ 30,000 \text { for single } \\
\text { filers, } \$ 40,000 \text { for } \\
\text { joint filers }\end{array}$ & $\begin{array}{l}\$ 30,000 \text { for single } \\
\text { filers, } \$ 40,000 \text { for } \\
\text { joint filers }\end{array}$ & $\begin{array}{l}\$ 30,000 \text { for single } \\
\text { filers, } \$ 40,000 \text { for } \\
\text { joint filers }\end{array}$ \\
\hline
\end{tabular}




\begin{tabular}{|c|c|c|c|c|c|c|}
\hline & 1984 & 1985 & 1986 & 1987 & 1988 & 1989 \\
\hline \multicolumn{7}{|l|}{ Tax credits } \\
\hline Child tax credit & N.A. & N.A. & N.A. & N.A. & N.A. & N.A. \\
\hline $\begin{array}{l}\text { Child and dependent care tax credit (non- } \\
\text { refundable)***** }\end{array}$ & $\begin{array}{l}\text { Maximum } \\
\text { expenditure eligible } \\
\text { for credit is } \$ 2,400 \\
\text { for one child, } \\
\$ 4,800 \text { for two or } \\
\text { more; maximimum } \\
\text { credit is } 20 \%-30 \% \\
\text { of expenditures }\end{array}$ & $\begin{array}{l}\text { Maximum } \\
\text { expenditure eligible } \\
\text { for credit is } \$ 2,400 \\
\text { for one child, } \\
\$ 4,800 \text { for two or } \\
\text { more; maximimum } \\
\text { credit is } 20 \%-30 \% \\
\text { of expenditures }\end{array}$ & $\begin{array}{l}\text { Maximum } \\
\text { expenditure eligible } \\
\text { for credit is } \$ 2,400 \\
\text { for one child, } \\
\$ 4,800 \text { for two or } \\
\text { more; maximimum } \\
\text { credit is } 20 \%-30 \% \\
\text { of expenditures }\end{array}$ & $\begin{array}{l}\text { Maximum } \\
\text { expenditure eligible } \\
\text { for credit is } \$ 2,400 \\
\text { for one child, } \\
\$ 4,800 \text { for two or } \\
\text { more; maximimum } \\
\text { credit is } 20 \%-30 \% \\
\text { of expenditures }\end{array}$ & $\begin{array}{l}\text { Maximum } \\
\text { expenditure eligible } \\
\text { for credit is } \$ 2,400 \\
\text { for one child, } \\
\$ 4,800 \text { for two or } \\
\text { more; maximimum } \\
\text { credit is } 20 \%-30 \% \\
\text { of expenditures }\end{array}$ & $\begin{array}{l}\text { Maximum expenditure } \\
\text { eligible for credit is } \\
\$ 2,400 \text { for one child, } \\
\$ 4,800 \text { for two or } \\
\text { more; maximimum } \\
\text { credit is } 20 \%-30 \% \text { of } \\
\text { expenditures }\end{array}$ \\
\hline EITC rate and maximum credit & $10 \%$, max. $\$ 500$ & $11 \%$, max. $\$ 550$ & $11 \%, \max . \$ 550$ & $\begin{array}{l}14 \%, \text { max. } \$ 851 \\
\text { indexed for inflation }\end{array}$ & $14 \%$, max. $\$ 874$ & $14 \%, \max . \$ 910$ \\
\hline EITC phaseout range and rate & $\begin{array}{l}\$ 6,000-\$ 10,000 \\
12.5 \%\end{array}$ & $\begin{array}{l}\$ 6,500-\$ 11,000 \\
12.22 \%\end{array}$ & $\begin{array}{l}\$ 6,500-\$ 11,000 \\
12.22 \%\end{array}$ & $\begin{array}{l}\$ 6,920-\$ 15,432 \text {, } \\
\text { indexed for } \\
\text { inflation, } 10 \%\end{array}$ & $\begin{array}{l}\$ 9,840-\$ 18,576 \\
10 \%\end{array}$ & $\begin{array}{l}\$ 10,240-\$ 19,340, \\
10 \%\end{array}$ \\
\hline \multicolumn{7}{|l|}{ Social Security [a] } \\
\hline Social Security tax rate (OASDI) [b] & $11.4 \%$ & $11.4 \%$ & $11.4 \%$ & $11.4 \%$ & $12.12 \%$ & $12.12 \%$ \\
\hline Hospital Insurance tax rate $(\mathrm{HI})[\mathrm{c}]$ & $2.6 \%$ & $2.7 \%$ & $2.9 \%$ & $2.9 \%$ & $2.9 \%$ & $2.9 \%$ \\
\hline OASDI taxable maximum earnings & 37,800 & 39,600 & 42,000 & 43,800 & 45,000 & 48,000 \\
\hline HI taxable maximum earnings [d] & 37,800 & 39,600 & 42,000 & 43,800 & 45,000 & 48,000 \\
\hline
\end{tabular}

\begin{tabular}{|c|c|c|c|c|c|c|}
\hline & 1990 & 1991 & 1992 & 1993 & 1994 & 1995 \\
\hline \multicolumn{7}{|l|}{ Income Tax } \\
\hline Number of tax brackets* & 4 & 3 & 3 & 5 & 5 & 5 \\
\hline Lowest individual income tax rate ${ }^{* *}$ & $15 \%$ & $15 \%$ & $15 \%$ & $15 \%$ & $15 \%$ & $15 \%$ \\
\hline $\begin{array}{l}\text { Lowest individual income single tax } \\
\text { bracket }\end{array}$ & $\$ 0-\$ 19,450$ & $\$ 0-\$ 20,350$ & $\$ 0-\$ 21,450$ & $\$ 0-\$ 22,100$ & $\$ 0-\$ 22,750$ & $\$ 0-\$ 23,350$ \\
\hline $\begin{array}{l}\text { Lowest individual income joint tax } \\
\text { bracket }\end{array}$ & $\$ 0-\$ 32,450$ & $\$ 0-\$ 34,000$ & $\$ 0-\$ 35,800$ & $\$ 0-\$ 36,900$ & $\$ 0-\$ 38,000$ & $\$ 0-\$ 39,999$ \\
\hline $\begin{array}{l}\text { Other individual income tax brackets } \\
\text { (percent)*,**** }\end{array}$ & 28,33 & 28 & 28 & $28,31,36$ & $28,31,36$ & $28,31,36$ \\
\hline $\begin{array}{l}\text { Highest individual income tax bracket } \\
\text { rate }\end{array}$ & $28 \%$ & $31 \%$ & $31 \%$ & $39.6 \%$ & $39.6 \%$ & $39.6 \%$ \\
\hline $\begin{array}{l}\text { Rate on long-term capital gains } \\
\text { Rate on dividends }\end{array}$ & $\begin{array}{l}28 \% \text { and } 15 \% \\
=\text { individual rates }\end{array}$ & $\begin{array}{l}28 \% \text { and } 15 \% \\
=\text { individual rates }\end{array}$ & $\begin{array}{l}28 \% \text { and } 15 \% \\
=\text { individual rates }\end{array}$ & $\begin{array}{l}28 \% \text { and } 15 \% \\
=\text { individual rates }\end{array}$ & $\begin{array}{l}28 \% \text { and } 15 \% \\
=\text { individual rates }\end{array}$ & $\begin{array}{l}28 \% \text { and } 15 \% \\
=\text { individual rates }\end{array}$ \\
\hline $\begin{array}{l}\text { Limitations on personal exemption and } \\
\text { itemized deductions }\end{array}$ & N.A. & $\begin{array}{l}\text { Personal exemption phases } \\
\text { out (PEP) between } \\
\$ 100,000 \text { and } \$ 222,500 \\
\text { (single), } \$ 150,000 \text { and } \\
\$ 272,500 \text { (joint). Limitation } \\
\text { on itemized deductions } \\
\text { (Pease) for AGI over } \\
\$ 100,000 . \text { Thresholds } \\
\text { indexed for inflation }\end{array}$ & $\begin{array}{l}\text { PEP and Pease, } \\
\text { thresholds indexed } \\
\text { for inflation }\end{array}$ & $\begin{array}{l}\text { PEP and Pease, } \\
\text { thresholds indexed } \\
\text { for inflation }\end{array}$ & $\begin{array}{l}\text { PEP and Pease, } \\
\text { thresholds indexed for } \\
\text { inflation }\end{array}$ & $\begin{array}{l}\text { PEP and Pease, } \\
\text { thresholds indexed } \\
\text { for inflation }\end{array}$ \\
\hline Standard Deduction & $\begin{array}{c}\$ 3,250 \text { (single } \\
\text { person) / } \$ 5,450 \\
\text { (married couple) }\end{array}$ & $\begin{array}{l}\$ 3,400 \text { (single person) / } \\
\$ 5,700 \text { (married couple) }\end{array}$ & $\begin{array}{c}\$ 3,600 \text { (single } \\
\text { person) } / \$ 6,000 \\
\text { (married couple) }\end{array}$ & $\begin{array}{c}\$ 3,700 \text { (single } \\
\text { person) / } \$ 6,200 \\
\text { (married couple) }\end{array}$ & $\begin{array}{c}\$ 3,800 \text { (single person) } \\
/ \$ 6,550 \text { (married } \\
\text { couple) }\end{array}$ & $\begin{array}{c}\$ 3,900 \text { (single } \\
\text { person) } / \$ 6,550 \\
\text { (married couple) }\end{array}$ \\
\hline AMT exemption ${ }^{* * * * *}$ & $\begin{array}{l}\$ 30,000 \text { for single } \\
\text { filers, } \$ 40,000 \text { for } \\
\text { joint filers }\end{array}$ & $\begin{array}{l}\$ 30,000 \text { for single filers, } \\
\$ 40,000 \text { for joint filers }\end{array}$ & $\begin{array}{l}\$ 30,000 \text { for single } \\
\text { filers, } \$ 40,000 \text { for } \\
\text { joint filers }\end{array}$ & $\begin{array}{l}\$ 30,000 \text { for single } \\
\text { filers, } \$ 40,000 \text { for } \\
\text { joint filers }\end{array}$ & $\begin{array}{l}\$ 33,750 \text { for single } \\
\text { filers, } \$ 45,000 \text { for } \\
\text { joint filers }\end{array}$ & $\begin{array}{l}\$ 33,750 \text { for single } \\
\text { filers, } \$ 45,000 \text { for } \\
\text { joint filers }\end{array}$ \\
\hline
\end{tabular}




\begin{tabular}{|c|c|c|c|c|c|c|}
\hline & 1990 & 1991 & 1992 & 1993 & 1994 & 1995 \\
\hline \multicolumn{7}{|l|}{ Tax credits } \\
\hline Child tax credit & N.A. & N.A. & N.A. & N.A. & N.A. & N.A. \\
\hline $\begin{array}{l}\text { Child and dependent care tax credit (non- } \\
\text { refundable)***** }\end{array}$ & $\begin{array}{l}\text { Maximum } \\
\text { expenditure eligible } \\
\text { for credit is } \$ 2,400 \\
\text { - for one child, } \$ 4,800 \\
\text { for two or more; } \\
\text { maximimum credit is } \\
20 \%-30 \% \text { of } \\
\text { expenditures }\end{array}$ & $\begin{array}{l}\text { Maximum expenditure } \\
\text { eligible for credit is } \$ 2,400 \\
\text { for one child, } \$ 4,800 \text { for } \\
\text { two or more; maximimum } \\
\text { credit is } 20 \%-30 \% \text { of } \\
\text { expenditures }\end{array}$ & $\begin{array}{l}\text { Maximum } \\
\text { expenditure eligible } \\
\text { for credit is } \$ 2,400 \\
\text { for one child, } \$ 4,800 \\
\text { for two or more; } \\
\text { maximimum credit is } \\
20 \%-30 \% \text { of } \\
\text { expenditures }\end{array}$ & $\begin{array}{l}\text { Maximum } \\
\text { expenditure eligible } \\
\text { for credit is } \$ 2,400 \\
\text { for one child, } \$ 4,800 \\
\text { for two or more; } \\
\text { maximimum credit is } \\
20 \%-30 \% \text { of } \\
\text { expenditures }\end{array}$ & $\begin{array}{l}\text { Maximum expenditure } \\
\text { eligible for credit is } \\
\$ 2,400 \text { for one child, } \\
\$ 4,800 \text { for two or } \\
\text { more; maximimum } \\
\text { credit is } 20 \%-30 \% \text { of } \\
\text { expenditures }\end{array}$ & $\begin{array}{l}\text { Maximum } \\
\text { expenditure eligible } \\
\text { for credit is } \$ 2,400 \\
\text { for one child, } \$ 4,800 \\
\text { for two or more; } \\
\text { maximimum credit is } \\
20 \%-30 \% \text { of } \\
\text { expenditures }\end{array}$ \\
\hline EITC rate and maximum credit & $14 \%$, max. $\$ 953$ & $\begin{array}{l}\text { One child: } 16.7 \% \text {, } \\
\text { maximum } \$ 1,192 \text {; two } \\
\text { children: } 17.3 \% \text {, maximum } \\
\$ 1,235\end{array}$ & $\begin{array}{l}\text { One child: } 17.6 \% \text {, } \\
\text { maximum } \$ 1,324 \text {; } \\
\text { two children: } 18.4 \% \text {, } \\
\text { maximum } \$ 1,384\end{array}$ & $\begin{array}{l}\text { One child: } 18.5 \% \text {, } \\
\text { maximum } \$ 1,434 \text {; } \\
\text { two children: } 19.5 \% \text {, } \\
\text { maximum } \$ 1,511\end{array}$ & $\begin{array}{l}\text { No children: } 7.65 \% \text {, } \\
\text { maximum } \$ 306 \text {; one } \\
\text { child: } 26.3 \% \text {, } \\
\text { maximum } \$ 2,038 \text {; two } \\
\text { children: } 30.0 \% \text {, } \\
\text { maximum } \$ 2,528\end{array}$ & $\begin{array}{l}\text { No children: } 7.65 \% \text {, } \\
\text { maximum } \$ 314 \text {; one } \\
\text { child: } 34 \% \text {, } \\
\text { maximum } \$ 2,094 \text {; } \\
\text { two children: } 36 \% \text {, } \\
\text { maximum } \$ 3,110\end{array}$ \\
\hline EITC phaseout range and rate & $\begin{array}{l}\$ 10,730-\$ 20,264, \\
10 \%\end{array}$ & $\begin{array}{l}\text { One child/two children: } \\
\$ 11,250-\$ 21,250 \\
11.93 \% / 12.36 \%\end{array}$ & $\begin{array}{l}\text { One child: } \$ 11,840- \\
\$ 22,370 \text {, two } \\
\text { children: } \$ 11,250 \text { - } \\
\$ 21,250 \\
12.57 \% / 13.14 \%\end{array}$ & $\begin{array}{l}\text { One child: } \$ 12,200- \\
\$ 23,050 \text {, two } \\
\text { children: } \$ 12,200- \\
\$ 23,050 \\
13.21 \% / 13.93 \%\end{array}$ & $\begin{array}{l}\text { No children: } \$ 5,000- \\
\$ 9,000 \text {, one child: } \\
\$ 11,000-\$ 23,755 \text {, two } \\
\text { children: } \$ 11,000- \\
\$ 25,296 \text {, } \\
7.65 \% / 15.98 \% / 17.68 \\
\%\end{array}$ & $\begin{array}{l}\text { No children: } \$ 5,130- \\
\$ 9,230 \text {, one child: } \\
\$ 11,290-\$ 24,396 \text {, } \\
\text { two children: } \\
\$ 11,290-\$ 26,673 \text {, } \\
7.65 \% / 15.98 \% / 20.2 \\
2 \%\end{array}$ \\
\hline \multicolumn{7}{|l|}{ Social Security [a] } \\
\hline Social Security tax rate (OASDI) [b] & $12.4 \%$ & $12.4 \%$ & $12.4 \%$ & $12.4 \%$ & $12.4 \%$ & $12.4 \%$ \\
\hline Hospital Insurance tax rate $(\mathrm{HI})[\mathrm{c}]$ & $2.9 \%$ & $2.9 \%$ & $2.9 \%$ & $2.9 \%$ & $2.9 \%$ & $2.9 \%$ \\
\hline OASDI taxable maximum earnings & 51,300 & 53,400 & 55,500 & 57,600 & 60,600 & 61,200 \\
\hline HI taxable maximum earnings [d] & 51,300 & 125,000 & 130,200 & 135,000 & no max. & no max. \\
\hline
\end{tabular}

\begin{tabular}{|c|c|c|c|c|c|c|}
\hline & 1996 & 1997 & 1998 & 1999 & 2000 & 2001 \\
\hline \multicolumn{7}{|l|}{ Income Tax } \\
\hline Number of tax brackets* & 5 & 5 & 5 & 5 & 5 & 5 \\
\hline Lowest individual income tax rate** & $15 \%$ & $15 \%$ & $15 \%$ & $15 \%$ & $15 \%$ & $15 \%$ \\
\hline $\begin{array}{l}\text { Lowest individual income single tax } \\
\text { bracket }\end{array}$ & $\$ 0-\$ 24,000$ & $\$ 0-\$ 24,650$ & $\$ 0-\$ 25,350$ & $\$ 0-\$ 25,750$ & $\$ 0-\$ 26,250$ & $\$ 0-\$ 27,050$ \\
\hline $\begin{array}{l}\text { Lowest individual income joint tax } \\
\text { bracket }\end{array}$ & $\$ 0-\$ 40,100$ & $\$ 0-\$ 41,200$ & $\$ 0-\$ 42,350$ & $\$ 0-\$ 43,050$ & $\$ 0-\$ 43,850$ & $\$ 0-\$ 45,200$ \\
\hline $\begin{array}{l}\text { Other individual income tax brackets } \\
\text { (percent)*,**** }\end{array}$ & $28,31,36$ & $28,31,36$ & $28,31,36$ & $28,31,36$ & $28,31,36$ & $27.5,30.5,35.5$ \\
\hline $\begin{array}{l}\text { Highest individual income tax bracket } \\
\text { rate }\end{array}$ & $39.6 \%$ & $39.6 \%$ & $39.6 \%$ & $39.6 \%$ & $39.6 \%$ & $39.10 \%$ \\
\hline Rate on long-term capital gains & $28 \%$ and $15 \%$ & $\begin{array}{l}10 \% \text { for tax payers in } \\
\text { the } 15 \% \text { bracket or } \\
\text { below, } 20 \% \text { for others }\end{array}$ & $\begin{array}{l}10 \% \text { for tax payers in } \\
\text { the } 15 \% \text { bracket or } \\
\text { below, } 20 \% \text { for others }\end{array}$ & $\begin{array}{l}10 \% \text { for tax payers in } \\
\text { the } 15 \% \text { bracket or } \\
\text { below, } 20 \% \text { for others }\end{array}$ & $\begin{array}{l}10 \% \text { for tax payers in } \\
\text { the } 15 \% \text { bracket or } \\
\text { below, } 20 \% \text { for others }\end{array}$ & $\begin{array}{l}10 \% \text { for tax payers in the } \\
15 \% \text { bracket or below, } \\
20 \% \text { for others }\end{array}$ \\
\hline Rate on dividends & $=$ individual rates & $=$ individual rates & $=$ individual rates & $=$ individual rates & $=$ individual rates & $=$ individual rates \\
\hline $\begin{array}{l}\text { Limitations on personal exemption and } \\
\text { itemized deductions }\end{array}$ & $\begin{array}{l}\text { PEP and Pease, } \\
\text { thresholds indexed for } \\
\text { inflation }\end{array}$ & $\begin{array}{l}\text { PEP and Pease, } \\
\text { thresholds indexed for } \\
\text { inflation }\end{array}$ & $\begin{array}{l}\text { PEP and Pease, } \\
\text { thresholds indexed for } \\
\text { inflation }\end{array}$ & $\begin{array}{l}\text { PEP and Pease, } \\
\text { thresholds indexed for } \\
\text { inflation }\end{array}$ & $\begin{array}{l}\text { PEP and Pease, } \\
\text { thresholds indexed for } \\
\text { inflation }\end{array}$ & $\begin{array}{l}\text { PEP and Pease, } \\
\text { thresholds indexed for } \\
\text { inflation }\end{array}$ \\
\hline Standard Deduction & $\begin{array}{l}\$ 4,000 \text { (single person) / } \\
\$ 6,700 \text { (married couple) }\end{array}$ & $\begin{array}{l}\$ 4,150 \text { (single person) / } \\
\$ 6,900 \text { (married couple) }\end{array}$ & $\begin{array}{l}\$ 4,250 \text { (single person) / } \\
\$ 7,100 \text { (married couple) }\end{array}$ & $\begin{array}{l}\$ 4,300 \text { (single person) / } \\
\$ 7,200 \text { (married couple) }\end{array}$ & $\begin{array}{l}\$ 4,400 \text { (single person) / } \\
\$ 7,350 \text { (married couple) }\end{array}$ & $\begin{array}{l}\$ 4,550 \text { (single person) / } \\
\$ 7,600 \text { (married couple) }\end{array}$ \\
\hline AMT exemption***** & $\begin{array}{r}\$ 33,750 \text { for single filers, } \\
\$ 45,000 \text { for joint filers }\end{array}$ & $\begin{array}{r}\$ 33,750 \text { for single filers, } \\
\$ 45,000 \text { for joint filers }\end{array}$ & $\begin{array}{l}\$ 33,750 \text { for single filers, } \\
\$ 45,000 \text { for joint filers }\end{array}$ & $\begin{array}{l}\$ 33,750 \text { for single filers, } \\
\$ 45,000 \text { for joint filers }\end{array}$ & $\begin{array}{l}\$ 33,750 \text { for single filers, } \\
\$ 45,000 \text { for joint filers }\end{array}$ & $\begin{array}{l}\$ 35,750 \text { for single filers, } \\
\$ 49,000 \text { for joint filers }\end{array}$ \\
\hline
\end{tabular}




\begin{tabular}{|c|c|c|c|c|c|c|}
\hline & 1996 & 1997 & 1998 & 1999 & 2000 & 2001 \\
\hline \multicolumn{7}{|l|}{ Tax credits } \\
\hline Child tax credit & N.A. & $\$ 500$ (non-refundable) & $\$ 500$ (non-refundable) & $\$ 500$ (non-refundable) & $\$ 500$ (non-refundable) & $\begin{array}{l}600 \$ \text {, refundable up to } \\
10 \% \text { earned income } \\
\text { above } \$ 10,000 \text {, } \\
\text { threshold indexed for } \\
\text { inflation }\end{array}$ \\
\hline $\begin{array}{l}\text { Child and dependent care tax credit } \\
\text { (non-refundable) }{ }^{* * * * *}\end{array}$ & $\begin{array}{l}\text { Maximum expenditure } \\
\text { eligible for credit is } \\
\$ 2,400 \text { for one child, } \\
\$ 4,800 \text { for two or more; } \\
\text { maximimum credit is } \\
20 \%-30 \% \text { of } \\
\text { expenditures }\end{array}$ & $\begin{array}{l}\text { Maximum expenditure } \\
\text { eligible for credit is } \\
\$ 2,400 \text { for one child, } \\
\$ 4,800 \text { for two or more; } \\
\text { maximimum credit is } \\
20 \%-30 \% \text { of } \\
\text { expenditures }\end{array}$ & $\begin{array}{l}\text { Maximum expenditure } \\
\text { eligible for credit is } \\
\$ 2,400 \text { for one child, } \\
\$ 4,800 \text { for two or more; } \\
\text { maximimum credit is } \\
20 \%-30 \% \text { of } \\
\text { expenditures }\end{array}$ & $\begin{array}{l}\text { Maximum expenditure } \\
\text { eligible for credit is } \\
\$ 2,400 \text { for one child, } \\
\$ 4,800 \text { for two or more; } \\
\text { maximimum credit is } \\
20 \%-30 \% \text { of } \\
\text { expenditures }\end{array}$ & $\begin{array}{l}\text { Maximum expenditure } \\
\text { eligible for credit is } \\
\$ 2,400 \text { for one child, } \\
\$ 4,800 \text { for two or more; } \\
\text { maximimum credit is } \\
20 \%-30 \% \text { of } \\
\text { expenditures }\end{array}$ & $\begin{array}{l}\text { Maximum expenditure } \\
\text { eligible for credit is } \\
\$ 2,400 \text { for one child, } \\
\$ 4,800 \text { for two or more; } \\
\text { maximimum credit is } \\
20 \%-30 \% \text { of } \\
\text { expenditures }\end{array}$ \\
\hline EITC rate and maximum credit & $\begin{array}{l}\text { No children: } 7.65 \% \text {, } \\
\text { maximum } \$ 323 \text {; one } \\
\text { child: } 34 \% \text {, maximum } \\
\$ 2,152 \text {; two children: } \\
40 \% \text {, maximum } \$ 3,556\end{array}$ & $\begin{array}{l}\text { No children: } 7.65 \% \text {, } \\
\text { maximum } \$ 332 \text {; one } \\
\text { child: } 34 \% \text {, maximum } \\
\$ 2,210 \text {; two children: } \\
40 \% \text {, maximum } \$ 3,656\end{array}$ & $\begin{array}{l}\text { No children: } 7.65 \% \text {, } \\
\text { maximum } \$ 341 \text {; one } \\
\text { child: } 34 \% \text {, maximum } \\
\$ 2,271 \text {; two children: } \\
40 \% \text {, maximum } \$ 3,756\end{array}$ & $\begin{array}{l}\text { No children: } 7.65 \% \text {, } \\
\text { maximum } \$ 347 \text {; one } \\
\text { child: } 34 \% \text {, maximum } \\
\$ 2,312 \text {; two children: } \\
40 \% \text {, maximum } \$ 3,816\end{array}$ & $\begin{array}{l}\text { No children: } 7.65 \% \text {, } \\
\text { maximum } \$ 353 \text {; one } \\
\text { child: } 34 \% \text {, maximum } \\
\$ 2,353 \text {; two children: } \\
40 \% \text {, maximum } \$ 3,888\end{array}$ & $\begin{array}{l}\text { No children: } 7.65 \% \text {, } \\
\text { maximum } \$ 364 \text {; one } \\
\text { child: } 34 \% \text {, maximum } \\
\$ 2,428 \text {; two children: } \\
40 \% \text {, maximum } \$ 4,008\end{array}$ \\
\hline EITC phaseout range and rate & $\begin{array}{l}\text { No children: } \$ 5,280 \text { - } \\
\$ 9,500 \text {, one child: } \\
\$ 11,610-\$ 25,078 \text {, two } \\
\text { children: } \$ 11,610 \text { - } \\
\$ 28,495 \text {, } \\
7.65 \% / 15.98 \% / 21.06 \\
\%\end{array}$ & $\begin{array}{l}\text { No children: } \$ 5,430- \\
\$ 9,770 \text {, one child: } \\
\$ 11,930-\$ 25,650 \text {, two } \\
\text { children: } \$ 11,930- \\
\$ 29,290 \text {, } \\
7.65 \% / 15.98 \% / 21.06 \%\end{array}$ & $\begin{array}{l}\text { No children: } \$ 5,570- \\
\$ 10,030 \text {, one child: } \\
\$ 12,260-\$ 26,473 \text {, two } \\
\text { children: } \$ 12,260- \\
\$ 30,095 \text {, } \\
7.65 \% / 15.98 \% / 21.06 \%\end{array}$ & $\begin{array}{l}\text { No children: } \$ 5,670 \text { - } \\
\$ 10,200 \text {, one child: } \\
\$ 12,460-\$ 26,928 \text {, two } \\
\text { children: } \$ 12,460 \text { - } \\
\$ 30,580 \text {, } \\
7.65 \% / 15.98 \% / 21.06 \\
\%\end{array}$ & $\begin{array}{l}\text { No children: } \$ 5,770 \text { - } \\
\$ 10,380 \text {, one child: } \\
\$ 12,690-\$ 27,413 \text {, two } \\
\text { children: } \$ 12,690 \text { - } \\
\$ 31,152 \text {, } \\
7.65 \% / 15.98 \% / 21.06 \\
\%\end{array}$ & $\begin{array}{l}\text { No children: } \$ 5,950- \\
\$ 10,710 \text {, one child: } \\
\$ 13,090-\$ 28,281 \text {, two } \\
\text { children: } \$ 13,090- \\
\$ 32,121 \text {, } \\
7.65 \% / 15.98 \% / 21.06 \%\end{array}$ \\
\hline \multicolumn{7}{|l|}{ Social Security [a] } \\
\hline Social Security tax rate (OASDI) [b] & $12.4 \%$ & $12.4 \%$ & $12.4 \%$ & $12.4 \%$ & $12.4 \%$ & $12.4 \%$ \\
\hline Hospital Insurance tax rate $(\mathrm{HI})[\mathrm{c}]$ & $2.9 \%$ & $2.9 \%$ & $2.9 \%$ & $2.9 \%$ & $2.9 \%$ & $2.9 \%$ \\
\hline OASDI taxable maximum earnings & 62,700 & 65,400 & 68,400 & 72,600 & 76,200 & 80,400 \\
\hline $\mathrm{HI}$ taxable maximum earnings $[\mathrm{d}]$ & no max. & no max. & no max. & no max. & no max. & no max. \\
\hline
\end{tabular}

\begin{tabular}{|c|c|c|c|c|c|c|}
\hline & 2002 & 2003 & 2004 & 2005 & 2006 & 2007 \\
\hline \multicolumn{7}{|l|}{ Income Tax } \\
\hline Number of tax brackets* & 6 & 6 & 6 & 6 & 6 & 6 \\
\hline Lowest individual income tax rate** & $10 \%$ & $10 \%$ & $10 \%$ & $10 \%$ & $10 \%$ & $10 \%$ \\
\hline $\begin{array}{l}\text { Lowest individual income single tax } \\
\text { bracket }\end{array}$ & $\$ 0-\$ 6,000$ & $\$ 0-\$ 7,000$ & $\$ 0-\$ 7,150$ & $\$ 0-\$ 7,300$ & $\$ 0-\$ 7,550$ & $\$ 0-\$ 7,825$ \\
\hline $\begin{array}{l}\text { Lowest individual income joint tax } \\
\text { bracket }\end{array}$ & $\$ 0-\$ 12,000$ & $\$ 0-\$ 14,000$ & $\$ 0-\$ 14,300$ & $\$ 0-\$ 14,600$ & $\$ 0-\$ 15,100$ & $\$ 0-\$ 15,650$ \\
\hline $\begin{array}{l}\text { Other individual income tax brackets } \\
\text { (percent)*,**** }\end{array}$ & $15,27,30,35$ & $15,25,28,33$ & $15,25,28,33$ & $15,25,28,33$ & $15,25,28,33$ & $15,25,28,33$ \\
\hline $\begin{array}{l}\text { Highest individual income tax bracket } \\
\text { rate }\end{array}$ & $38.6 \%$ & $35 \%$ & $35 \%$ & $35 \%$ & $35 \%$ & $35 \%$ \\
\hline Rate on long-term capital gains & $\begin{array}{l}10 \% \text { for tax payers in } \\
\text { the } 15 \% \text { bracket or } \\
\text { below, } 20 \% \text { for others }\end{array}$ & $\begin{array}{l}5 \% \text { for taxpayers in the } \\
15 \% \text { bracket; } 15 \% \text { for } \\
\text { other brackets }\end{array}$ & $\begin{array}{l}\text { e } 5 \% \text { for taxpayers in the } \\
15 \% \text { bracket; } 15 \% \text { for } \\
\text { other brackets }\end{array}$ & $\begin{array}{l}5 \% \text { for taxpayers in the } \\
\text { or } 15 \% \text { bracket; } 15 \% \text { for } \\
\text { other brackets }\end{array}$ & $\begin{array}{l}5 \% \text { for taxpayers in the } 5 \% \\
15 \% \text { bracket; } 15 \% \text { for th } \\
\text { other brackets }\end{array}$ & $\begin{array}{l}5 \% \text { for taxpayers in } \\
\text { the } 15 \% \text { bracket; } \\
15 \% \text { for other }\end{array}$ \\
\hline Rate on dividends & $=$ individual rates & $\begin{array}{l}5 \% \text { for taxpayers in the } \\
15 \% \text { bracket; } 15 \% \text { for } \\
\text { other brackets }\end{array}$ & $\begin{array}{l}\text { e } 5 \% \text { for taxpayers in the } \\
\text { 15\% bracket; } 15 \% \text { for } \\
\text { other brackets }\end{array}$ & $\begin{array}{l}\text { 5\% for taxpayers in the } \\
\text { ot } 15 \% \text { bracket; } 15 \% \text { for } \\
\text { other brackets }\end{array}$ & $\begin{array}{l}5 \% \text { for taxpayers in the } 5 \% \\
15 \% \text { bracket; } 15 \% \text { for th } \\
\text { other brackets }\end{array}$ & $\begin{array}{l}5 \% \text { for taxpayers in } \\
\text { the } 15 \% \text { bracket; } \\
15 \% \text { for other }\end{array}$ \\
\hline $\begin{array}{l}\text { Limitations on personal exemption and } \\
\text { itemized deductions }\end{array}$ & $\begin{array}{l}\text { PEP and Pease, } \\
\text { thresholds indexed for } \\
\text { inflation }\end{array}$ & $\begin{array}{l}\text { PEP and Pease, } \\
\text { thresholds indexed for } \\
\text { inflation }\end{array}$ & $\begin{array}{l}\text { PEP and Pease, } \\
\text { thresholds indexed for } \\
\text { inflation }\end{array}$ & $\begin{array}{l}\text { PEP and Pease, } \\
\text { thresholds indexed for } \\
\text { inflation }\end{array}$ & $\begin{array}{ll}\text { PEP and Pease limits on } & \mathrm{PI} \\
\text { personal exemptions and } & \text { on } \\
\text { itemized deductions } & \text { ite } \\
\text { reduced by } 1 / 3, & \text { re } \\
\text { thresholds indexed for } & \text { th } \\
\text { inflation } & \text { fo }\end{array}$ & $\begin{array}{l}\text { PEP and Pease limits } \\
\text { on personal } \\
\text { exemptions and } \\
\text { itemized deductions } \\
\text { reduced by } 1 / 3 \text {, } \\
\text { thresholds indexed } \\
\text { for inflation }\end{array}$ \\
\hline Standard Deduction & $\begin{array}{l}\$ 4,700 \text { (single person) / } \\
\$ 7,850 \text { (married couple) }\end{array}$ & $\begin{array}{l}\$ 4,750 \text { (single person) / } \\
\$ 9,500 \text { (married couple) }\end{array}$ & $\begin{array}{l}\$ 4,850 \text { (single person) / } \\
\$ 9,700 \text { (married couple) }\end{array}$ & $\begin{array}{c}\$ 5,000 \text { (single person) } / \\
\$ 10,000 \text { (married } \\
\text { couple) }\end{array}$ & $\begin{array}{c}\$ 5,150 \text { ( single person) } / \\
\$ 10,300 \text { (married } \\
\text { couple) }\end{array}$ & $\begin{array}{c}\$ 5,350 \text { (single } \\
\text { person) } / \$ 10,700 \\
\text { (married couple) }\end{array}$ \\
\hline AMT exemption***** & $\begin{array}{l}\$ 35,750 \text { for single filers, } \\
\$ 49,000 \text { for joint filers }\end{array}$ & $\begin{array}{l}\$ 40,250 \text { for single filers, } \\
\$ 58,000 \text { for joint filers }\end{array}$ & $\begin{array}{l}\$ 40,250 \text { for single filers, } \\
\$ 58,000 \text { for joint filers }\end{array}$ & $\begin{array}{l}\$ 40,250 \text { for single filers, } \\
\$ 58,000 \text { for joint filers }\end{array}$ & $\begin{array}{l}\$ 42,500 \text { for single filers, } \\
\$ 62,550 \text { for joint filers }\end{array}$ & $\begin{array}{c}\$ 44,350 \text { for single } \\
\text { filers, } \$ 66,250 \text { for } \\
\text { joint filers }\end{array}$ \\
\hline
\end{tabular}




\begin{tabular}{|c|c|c|c|c|c|c|}
\hline & 2002 & 2003 & 2004 & 2005 & 2006 & 2007 \\
\hline \multicolumn{7}{|l|}{ Tax credits } \\
\hline Child tax credit & $\begin{array}{l}600 \$ \text {, refundable up to } \\
10 \% \text { earned income } \\
\text { above } \$ 10,350\end{array}$ & $\begin{array}{l}1,000 \$ \text {, refundable up to } \\
10 \% \text { earned income } \\
\text { above } \$ 10,500\end{array}$ & $\begin{array}{l}1,000 \$ \text {, refundable up to } \\
15 \% \text { earned income } \\
\text { above } \$ 10,750\end{array}$ & $\begin{array}{l}1,000 \$ \text {, refundable up } \\
\text { to } 15 \% \text { earned income } \\
\text { above } \$ 11,000\end{array}$ & $\begin{array}{l}1,000 \$ \text {, refundable up to } \\
15 \% \text { earned income } \\
\text { above } \$ 11,300\end{array}$ & $\begin{array}{l}1,000 \$ \text {, refundable up } \\
\text { to } 15 \% \text { earned } \\
\text { income above } \\
\$ 11,750\end{array}$ \\
\hline $\begin{array}{l}\text { Child and dependent care tax credit (non- } \\
\text { refundable)***** }\end{array}$ & $\begin{array}{l}\text { Maximum eligible } \\
\text { expenses are } \$ 3,000 \text { for } \\
1 \text { child; } \$ 6,000 \text { for } 2 \text { or } \\
\text { more; maximum credit is } \\
35 \% \text { (phasing down to } \\
20 \% \text { at } \$ 15,000 \text { of } A G I \text { ) }\end{array}$ & $\begin{array}{l}\text { Maximum eligible } \\
\text { expenses are } \$ 3,000 \text { for } 1 \\
\text { child; } \$ 6,000 \text { for } 2 \text { or } \\
\text { more; maximum credit is } \\
35 \% \text { (phasing down to } \\
20 \% \text { at } \$ 15,000 \text { of AGI) }\end{array}$ & $\begin{array}{l}\text { Maximum eligible } \\
\text { expenses are } \$ 3,000 \text { for } 1 \\
\text { child; } \$ 6,000 \text { for } 2 \text { or } \\
\text { more; maximum credit is } \\
35 \% \text { (phasing down to } \\
20 \% \text { at } \$ 15,000 \text { of AGI) }\end{array}$ & $\begin{array}{l}\text { Maximum eligible } \\
\text { expenses are } \$ 3,000 \text { for } \\
1 \text { child; } \$ 6,000 \text { for } 2 \text { or } \\
\text { more; maximum credit } \\
\text { is } 35 \% \text { (phasing down } \\
\text { to } 20 \% \text { at } \$ 15,000 \text { of } \\
\text { AGI) }\end{array}$ & $\begin{array}{l}\text { Maximum eligible } \\
\text { expenses are } \$ 3,000 \text { for } \\
1 \text { child; } \$ 6,000 \text { for } 2 \text { or } \\
\text { more; maximum credit is } \\
35 \% \text { (phasing down to } \\
20 \% \text { at } \$ 15,000 \text { of } A G I \text { ) }\end{array}$ & $\begin{array}{l}\text { Maximum eligible } \\
\text { expenses are } \$ 3,000 \\
\text { for } 1 \text { child; } \$ 6,000 \text { for } \\
2 \text { or more; maximum } \\
\text { credit is } 35 \% \\
\text { (phasing down to } \\
20 \% \text { at } \$ 15,000 \text { of } \\
\text { AGI) }\end{array}$ \\
\hline EITC rate and maximum credit & $\begin{array}{l}\text { No children: } 7.65 \% \text {, } \\
\text { maximum } \$ 376 \text {; one } \\
\text { child: } 34 \% \text {, maximum } \\
\$ 2,506 \text {; two children: } \\
40 \% \text {, maximum } \$ 4,140\end{array}$ & $\begin{array}{l}\text { No children: } 7.65 \% \text {, } \\
\text { maximum } \$ 382 \text {; one } \\
\text { child: } 34 \% \text {, maximum } \\
\$ 2,547 \text {; two children: } \\
40 \% \text {, maximum } \$ 4,204\end{array}$ & $\begin{array}{l}\text { No children: } 7.65 \% \text {, } \\
\text { maximum } \$ 390 \text {; one } \\
\text { child: } 34 \% \text {, maximum } \\
\$ 2,604 \text {; two children: } \\
40 \% \text {, maximum } \$ 4,300\end{array}$ & $\begin{array}{l}\text { No children: } 7.65 \% \text {, } \\
\text { maximum } \$ 399 \text {; one } \\
\text { child: } 34 \% \text {, maximum } \\
\$ 2,662 \text {; two children: } \\
40 \% \text {, maximum } \$ 4,400\end{array}$ & $\begin{array}{l}\text { No children: } 7.65 \% \text {, } \\
\text { maximum } \$ 412 \text {; one } \\
\text { child: } 34 \% \text {, maximum } \\
\$ 2,747 \text {; two children: } \\
40 \% \text {, maximum } \$ 4,536\end{array}$ & $\begin{array}{l}\text { No children: } 7.65 \% \text {, } \\
\text { maximum } \$ 428 \text {; one } \\
\text { child: } 34 \% \text {, maximum } \\
\$ 2,853 \text {; two children: } \\
40 \% \text {, maximum } \\
\$ 4,716\end{array}$ \\
\hline EITC phaseout range and rate & $\begin{array}{l}\text { No children: } \$ 6,150 \text { - } \\
\$ 11,060 \text {, one child: } \\
\$ 13,520-\$ 29,201 \text {, two } \\
\text { children: } \$ 13,520- \\
\$ 33,178 \text {. } \\
\text { Starting/ending points } \\
\text { increased by } \$ 1,000 \text { for } \\
\text { joint filers. } \\
7.65 \% / 15.98 \% / 21.06 \%\end{array}$ & $\begin{array}{l}\text { No children: } \$ 6,240- \\
\$ 11,230 \text {, one child: } \\
\$ 13,730-\$ 29,666 \text {, two } \\
\text { children: } \$ 13,730- \\
\$ 33,692 \text {. Increased by } \\
\$ 1,000 \text { for joint filers. } \\
7.65 \% / 15.98 \% / 21.06 \%\end{array}$ & $\begin{array}{l}\text { No children: } \$ 6,390- \\
\$ 11,490 \text {, one child: } \\
\$ 14,040-\$ 30,338 \text {, two } \\
\text { children: } \$ 14,040- \\
\$ 34,458 \text {. Increased by } \\
\$ 1,000 \text { for joint filers. } \\
7.65 \% / 15.98 \% / 21.06 \%\end{array}$ & $\begin{array}{l}\text { No children: } \$ 6,530 \text { - } \\
\$ 11,750 \text {, one child: } \\
\$ 14,370-\$ 31,030 \text {, two } \\
\text { children: } \$ 14,370- \\
\$ 35,263 \text {. Increased by } \\
\$ 2,000 \text { for joint filers. } \\
7.65 \% / 15.98 \% / 21.06 \\
\%\end{array}$ & $\begin{array}{l}\text { No children: } \$ 6,740- \\
\$ 12,120 \text {, one child: } \\
\$ 14,810-\$ 32,001 \text {, two } \\
\text { children: } \$ 14,810- \\
\$ 36,348 \text {. Increased by } \\
\$ 2,000 \text { for joint filers. } \\
7.65 \% / 15.98 \% / 21.06 \%\end{array}$ & $\begin{array}{l}\text { No children: } \$ 7,000- \\
\$ 12,590 \text {, one child: } \\
\$ 15,390-\$ 33,241 \text {, } \\
\text { two children: } \$ 15,390 \\
\$ 37,783 \text {. Increased by } \\
\$ 2,000 \text { for joint filers. } \\
7.65 \% / 15.98 \% / \\
21.06 \%\end{array}$ \\
\hline \multicolumn{7}{|l|}{ Social Security [a] } \\
\hline Social Security tax rate (OASDI) [b] & $12.4 \%$ & $12.4 \%$ & $12.4 \%$ & $12.4 \%$ & $12.4 \%$ & $12.4 \%$ \\
\hline Hospital Insurance tax rate $(\mathrm{HI})[\mathrm{c}]$ & $2.9 \%$ & $2.9 \%$ & $2.9 \%$ & $2.9 \%$ & $2.9 \%$ & $2.9 \%$ \\
\hline OASDI taxable maximum earnings & 84,900 & 87,000 & 87,900 & 90,000 & 94,200 & 97,500 \\
\hline HI taxable maximum earnings [d] & no max. & no max. & no max. & no max. & no max. & no max. \\
\hline
\end{tabular}




\begin{tabular}{|c|c|c|c|c|c|}
\hline & 2008 & 2009 & & 2008 & 2009 \\
\hline Income Tax & & & Social Security [a] & & \\
\hline Number of tax brackets* & 6 & 6 & Social Security tax rate (OASDI) & $12.4 \%$ & $12.4 \%$ \\
\hline $\begin{array}{l}\text { Lowest individual income } \\
\text { tax rate** }\end{array}$ & $10 \%$ & $10 \%$ & Hospital Insurance tax rate $(\mathrm{HI})$ & $2.9 \%$ & $2.9 \%$ \\
\hline $\begin{array}{l}\text { Lowest individual income } \\
\text { single tax bracket }\end{array}$ & $\$ 0-\$ 8,025$ & $\$ 0-\$ 8,350$ & OASDI taxable maximum earnings & 102,000 & 106,800 \\
\hline $\begin{array}{l}\text { Lowest individual income } \\
\text { joint tax bracket }\end{array}$ & $\$ 0-\$ 16,050$ & $\$ 0-\$ 16,700$ & $\mathrm{HI}$ taxable maximum earnings & no $\max$. & no $\max$. \\
\hline $\begin{array}{l}\text { Other individual income tax } \\
\text { brackets (percent)*,**** }\end{array}$ & $15,25,28,33$ & $15,25,28,33$ & Tax credits & & \\
\hline $\begin{array}{l}\text { Highest individual income } \\
\text { tax bracket rate }\end{array}$ & $35 \%$ & $35 \%$ & Child tax credit & $\begin{array}{l}1,000 \$ \text {, refundable up to } 15 \% \\
\text { earned income above } \$ 8,500\end{array}$ & $\begin{array}{l}1,000 \$ \text {, refundable up to } 15 \% \\
\text { earned income above } \$ 3,000\end{array}$ \\
\hline $\begin{array}{l}\text { Rate on long-term capital } \\
\text { gains }\end{array}$ & $\begin{array}{l}0 \% \text { for taxpayers in the } 10 \% \\
\text { and } 15 \% \text { bracket; } 15 \% \text { for } \\
\text { other brackets }\end{array}$ & $\begin{array}{l}0 \% \text { for taxpayers in the } \\
10 \% \text { and } 15 \% \text { bracket; } \\
15 \% \text { for other brackets }\end{array}$ & $\begin{array}{l}\text { Child and dependent care tax } \\
\text { credit (non-refundable)***** }\end{array}$ & $\begin{array}{l}\text { Maximum eligible expenses are } \\
\$ 3,000 \text { for } 1 \text { child; } \$ 6,000 \text { for } \\
2 \text { or more; maximum credit is } \\
35 \% \text { (phasing down to } 20 \% \text { at } \\
\$ 15,000 \text { of } A G I \text { ) }\end{array}$ & $\begin{array}{l}\text { Maximum eligible expenses are } \\
\$ 3,000 \text { for } 1 \text { child; } \$ 6,000 \text { for } 2 \\
\text { or more; maximum credit is } 35 \% \\
\text { (phasing down to } 20 \% \text { at } \$ 15,000 \\
\text { of AGI) }\end{array}$ \\
\hline Rate on dividends & $\begin{array}{l}0 \% \text { for taxpayers in the } 10 \% \\
\text { and } 15 \% \text { bracket; } 15 \% \text { for } \\
\text { other brackets }\end{array}$ & $\begin{array}{l}0 \% \text { for taxpayers in the } \\
10 \% \text { and } 15 \% \text { bracket; } \\
15 \% \text { for other brackets }\end{array}$ & EITC rate and maximum credit & $\begin{array}{l}\text { No children: } 7.65 \% \text {, maximum } \\
\$ 438 \text {; one child: } 34 \% \text {, } \\
\text { maximum } \$ 2,917 \text {; two } \\
\text { children: } 40 \% \text {, maximum } \\
\$ 4,824\end{array}$ & $\begin{array}{l}\text { No children: } 7.65 \% \text {, maximum } \\
\$ 457 \text {; one child: } 34 \% \text {, maximum } \\
\$ 3,043 \text {; two children: } 40 \% \text {, } \\
\text { maximum } \$ 5,028 \text {; three children } \\
45 \% \text {, maximum } \$ 5,657\end{array}$ \\
\hline $\begin{array}{l}\text { Limitations on personal } \\
\text { exemption and itemized } \\
\text { deductions }\end{array}$ & $\begin{array}{l}\text { PEP and Pease limits on } \\
\text { personal exemptions and } \\
\text { itemized deductions reduced } \\
\text { by } 2 / 3 \text {, thresholds indexed } \\
\text { for inflation }\end{array}$ & $\begin{array}{l}\text { PEP and Pease limits on } \\
\text { personal exemptions and } \\
\text { itemized deductions } \\
\text { reduced by } 2 / 3 \text {, thresholds } \\
\text { indexed for inflation }\end{array}$ & EITC phaseout range and rate & $\begin{array}{l}\text { No children: } \$ 7,160-\$ 12,880 \text {, } \\
\text { one child: } \$ 15,740-\$ 33,995 \text {, } \\
\text { two children: } \$ 15,740-\end{array}$ & $\begin{array}{l}\text { No children: } \$ 7,470-\$ 13,440 \text {, one } \\
\text { child: } \$ 16,420-\$ 35,463 \text {, two } \\
\text { children: } \$ 16,420-\$ 40,295 \text {, three } \\
\text { children: } \$ 16,420-\$ 43,279 \text {. }\end{array}$ \\
\hline Standard Deduction & $\begin{array}{l}\$ 5,450 \text { (single person) / } \\
\$ 10,900 \text { (married couple) }\end{array}$ & $\begin{array}{l}\$ 5,700 \text { (single person) / } \\
\$ 11,400 \text { (married couple) }\end{array}$ & & $\begin{array}{l}\$ 38,646 \text {. Increased by } \$ 3,000 \\
\text { (indexed for inflation) for joint } \\
\text { filers. } 7.65 \% / 15.98 \% / 21.06 \%\end{array}$ & $\begin{array}{l}\text { Increased by } \$ 5,000 \text { for joint } \\
\text { filers. } \\
7.65 \% / 15.98 \% / 21.06 \% / 21.06 \%\end{array}$ \\
\hline AMT exemption $* * * * *$ & $\begin{array}{l}\$ 46,200 \text { for single filers, } \\
\$ 69,950 \text { for joint filers }\end{array}$ & $\begin{array}{c}\$ 46,700 \text { for single filers, } \\
\$ 70,950 \text { for joint filers }\end{array}$ & & & \\
\hline
\end{tabular}

Notes:

* Married couple filing jointly

** Indexing of income brackets for individual income tax began in 1985 under ERTA81 except for 1987 and 1988 when brackets were not indexed because of rate changes;

Changes in bracket amounts for 1985-1986, 1989-2000, and 2004-2007 occured as a result of indexing for inflation rather than from a change in tax legislation

*** $0 \%$ rate existed below these brackets until 1986

**** For years 1988-1990 rate applicable to highest income bracket is not the highest rate: $28 \%$ rate is applicable to two income brackets - the highest bracket and a lower one

***** Not indexed for inflation

[a] The taxable maximum for 1979-81 was set by statute; all other amounts were determined under automatic adjustment provisions of the Social Security Act

according to the national average wage index. The tax rate refers to the combined rate for employers and employees.

[b] OASDI: Old-Age, Survivors, and Disability Insurance program

[c] HI: Medicare's Hospital Insurance program

[d] The upper limit on earnings subject to HI was repealed by the Omnibus Budget Reconciliation Act of 1993

Sources: Tax Policy Center (http://www.taxpolicycenter.org/taxfacts/index.cfm), Social Security Administration (http://www.ssa.gov/OACT/COLA/cbb.html

and http://www.ssa.gov/OACT/ProgData/taxRates.html), last accessed May 2011 
Table 2: Decomposing changes in income distribution over time

\begin{tabular}{|c|c|c|c|c|c|c|c|c|c|c|c|c|}
\hline $\begin{array}{l}\text { data year: } \\
\text { uprated to: }\end{array}$ & \multirow[b]{2}{*}{1978} & $\begin{array}{l}1978 \\
1980\end{array}$ & 1980 & $\begin{array}{l}1978 \\
1980\end{array}$ & 1980 & \multirow{2}{*}{$\begin{array}{c}\text { Total } \\
\text { change }\end{array}$} & \multicolumn{2}{|c|}{ Decomposition I } & \multicolumn{2}{|c|}{ Decomposition II } & \multicolumn{2}{|c|}{$\begin{array}{l}\text { Shorrocks-Shapley } \\
\text { Decomposition }\end{array}$} \\
\hline $\begin{array}{l}\text { policy year: } \\
\text { uprated to: }\end{array}$ & & $\begin{array}{l}1978 \\
1980\end{array}$ & $\begin{array}{l}1978 \\
1980\end{array}$ & 1980 & 1980 & & $\begin{array}{l}\text { Tax policy } \\
\text { effect }\end{array}$ & $\begin{array}{l}\text { Other } \\
\text { effect }\end{array}$ & $\begin{array}{l}\text { Tax policy } \\
\text { effect }\end{array}$ & $\begin{array}{l}\text { Other } \\
\text { effect }\end{array}$ & $\begin{array}{l}\text { Tax policy } \\
\text { effect }\end{array}$ & $\begin{array}{l}\text { Other } \\
\text { effect }\end{array}$ \\
\hline & (0) & (1) & (2) & (3) & (4) & (4)-(0) & (4)-(2) & $(2)-(1)$ & (3)-(1) & (4)-(3) & $\begin{array}{l}\text { Mean of } \\
(4)-(2),(3)-(1)\end{array}$ & $\begin{array}{l}\text { Mean of } \\
(2)-(1),(4)-(3)\end{array}$ \\
\hline \multicolumn{13}{|l|}{ Inequality } \\
\hline Gini & 29.70 & 29.70 & 30.96 & 29.10 & 30.38 & 0.68 & -0.58 & 1.26 & -0.60 & 1.28 & -0.59 & 1.27 \\
\hline P90/P10 & 4.63 & 4.63 & 4.90 & 4.48 & 4.78 & 0.15 & -0.12 & 0.26 & -0.15 & 0.30 & -0.13 & 0.28 \\
\hline P90/P50 & 1.82 & 1.82 & 1.87 & 1.79 & 1.84 & 0.01 & -0.03 & 0.04 & -0.03 & 0.05 & -0.03 & 0.05 \\
\hline P50/P10 & 2.54 & 2.54 & 2.62 & 2.50 & 2.60 & 0.06 & -0.02 & 0.08 & -0.04 & 0.10 & -0.03 & 0.09 \\
\hline
\end{tabular}

Measures are based on equivalized income using the square-root of househohld size scale. Gini multiplied by 100. Uprating according the level of price inflation.

\begin{tabular}{|c|c|c|c|c|c|c|c|c|c|c|c|c|}
\hline \multirow{3}{*}{$\begin{array}{l}\text { data year: } \\
\text { uprated to: } \\
\text { policy year: } \\
\text { uprated to: }\end{array}$} & \multirow{2}{*}{$\begin{array}{l}1981 \\
1981\end{array}$} & $\begin{array}{l}1981 \\
1984\end{array}$ & 1984 & $\begin{array}{l}1981 \\
1984\end{array}$ & 1984 & \multirow{2}{*}{$\begin{array}{c}\text { Total } \\
\text { change }\end{array}$} & \multicolumn{4}{|c|}{ Decomposition I Decomposition II } & \multicolumn{2}{|c|}{$\begin{array}{c}\text { Shorrocks-Shapley } \\
\text { Decomposition }\end{array}$} \\
\hline & & $\begin{array}{l}1981 \\
1984\end{array}$ & $\begin{array}{l}1981 \\
1984\end{array}$ & 1984 & 1984 & & $\begin{array}{c}\text { Tax } \\
\text { policy } \\
\text { effect }\end{array}$ & $\begin{array}{l}\text { Other } \\
\text { effect }\end{array}$ & $\begin{array}{c}\text { Tax } \\
\text { policy } \\
\text { effect }\end{array}$ & $\begin{array}{l}\text { Other } \\
\text { effect }\end{array}$ & $\begin{array}{c}\text { Tax policy } \\
\text { effect }\end{array}$ & Other effect \\
\hline & (0) & (1) & (2) & (3) & (4) & (4)-(0) & (4)-(2) & $(2)-(1)$ & (3)-(1) & (4)-(3) & $\begin{array}{l}\text { Mean of } \\
(4)-(2),(3)-(1)\end{array}$ & $\begin{array}{c}\text { Mean of } \\
(2)-(1),(4)-(3)\end{array}$ \\
\hline \multicolumn{13}{|l|}{ Inequality } \\
\hline Gini & 30.86 & 30.86 & 32.30 & 31.86 & 33.28 & 2.42 & 0.98 & 1.44 & 1.00 & 1.42 & 0.99 & 1.43 \\
\hline P90/P10 & 4.94 & 4.94 & 5.46 & 5.30 & 5.77 & 0.83 & 0.31 & 0.53 & 0.36 & 0.47 & 0.33 & 0.50 \\
\hline P90/P50 & 1.83 & 1.83 & 1.90 & 1.89 & 1.96 & 0.12 & 0.05 & 0.07 & 0.06 & 0.06 & 0.06 & 0.07 \\
\hline P50/P10 & 2.69 & 2.69 & 2.87 & 2.79 & 2.95 & 0.26 & 0.09 & 0.17 & 0.10 & 0.16 & 0.09 & 0.17 \\
\hline
\end{tabular}

Measures are based on equivalized income using the square-root of househohld size scale. Gini multiplied by 100. Uprating according the level of price inflation. 
Table 3: Decomposing changes in income distribution over time (cont.)

\begin{tabular}{|c|c|c|c|c|c|c|c|c|c|c|c|c|}
\hline \multirow{3}{*}{$\begin{array}{l}\text { data year: } \\
\text { uprated to: } \\
\text { policy year: } \\
\text { uprated to: }\end{array}$} & \multirow{2}{*}{$\begin{array}{l}1986 \\
1986\end{array}$} & $\begin{array}{l}1986 \\
1988\end{array}$ & 1988 & $\begin{array}{l}1986 \\
1988\end{array}$ & 1988 & \multirow{2}{*}{$\begin{array}{c}\text { Total } \\
\text { change }\end{array}$} & \multicolumn{4}{|c|}{ Decomposition I Decomposition II } & \multicolumn{2}{|c|}{$\begin{array}{c}\text { Shorrocks-Shapley } \\
\text { Decomposition }\end{array}$} \\
\hline & & $\begin{array}{l}1986 \\
1988\end{array}$ & $\begin{array}{l}1986 \\
1988\end{array}$ & 1988 & 1988 & & $\begin{array}{c}\text { Tax } \\
\text { policy } \\
\text { effect }\end{array}$ & $\begin{array}{l}\text { Other } \\
\text { effect }\end{array}$ & $\begin{array}{c}\text { Tax } \\
\text { policy } \\
\text { effect }\end{array}$ & $\begin{array}{l}\text { Other } \\
\text { effect }\end{array}$ & $\begin{array}{c}\text { Tax policy } \\
\text { effect }\end{array}$ & Other effect \\
\hline & (0) & (1) & (2) & (3) & (4) & (4)-(0) & $(4)-(2)$ & $(2)-(1)$ & (3)-(1) & $(4)-(3)$ & $\begin{array}{l}\text { Mean of } \\
(4)-(2),(3)-(1)\end{array}$ & $\begin{array}{l}\text { Mean of } \\
(2)-(1),(4)-(3)\end{array}$ \\
\hline \multicolumn{13}{|l|}{ Inequality } \\
\hline Gini & 33.75 & 33.75 & 34.07 & 34.76 & 35.09 & 1.34 & 1.02 & 0.32 & 1.01 & 0.33 & 1.02 & 0.32 \\
\hline P90/P10 & 5.87 & 5.87 & 5.93 & 5.98 & 6.02 & 0.15 & 0.09 & 0.06 & 0.12 & 0.03 & 0.10 & 0.05 \\
\hline P90/P50 & 1.96 & 1.96 & 1.98 & 2.00 & 2.02 & 0.06 & 0.04 & 0.02 & 0.04 & 0.02 & 0.04 & 0.02 \\
\hline P50/P10 & 3.00 & 3.00 & 3.00 & 2.99 & 2.98 & -0.02 & -0.02 & 0.00 & -0.01 & -0.01 & -0.01 & 0.00 \\
\hline
\end{tabular}

Measures are based on equivalized income using the square-root of househohld size scale. Gini multiplied by 100. Uprating according the level of price inflation.

\begin{tabular}{|c|c|c|c|c|c|c|c|c|c|c|c|c|}
\hline \multirow{3}{*}{$\begin{array}{l}\text { data year: } \\
\text { uprated to: } \\
\text { policy year: } \\
\text { uprated to: }\end{array}$} & \multirow{2}{*}{$\begin{array}{l}1986 \\
1986\end{array}$} & $\begin{array}{l}1986 \\
1988\end{array}$ & \multirow{2}{*}{$\begin{array}{l}1988 \\
1986\end{array}$} & \multirow{2}{*}{$\begin{array}{l}1986 \\
1988 \\
1988\end{array}$} & \multirow{2}{*}{$\begin{array}{l}1988 \\
1988\end{array}$} & \multirow{2}{*}{$\begin{array}{c}\text { Total } \\
\text { change }\end{array}$} & \multicolumn{4}{|c|}{ Decomposition I Decomposition II } & \multicolumn{2}{|c|}{$\begin{array}{l}\text { Shorrocks-Shapley } \\
\text { Decomposition }\end{array}$} \\
\hline & & $\begin{array}{l}1986 \\
1988\end{array}$ & & & & & $\begin{array}{c}\text { Tax } \\
\text { policy } \\
\text { effect }\end{array}$ & $\begin{array}{l}\text { Other } \\
\text { effect }\end{array}$ & $\begin{array}{c}\text { Tax } \\
\text { policy } \\
\text { effect }\end{array}$ & $\begin{array}{l}\text { Other } \\
\text { effect }\end{array}$ & $\begin{array}{c}\text { Tax policy } \\
\text { effect }\end{array}$ & Other effect \\
\hline & (0) & (1) & $(2)$ & (3) & (4) & (4)-(0) & $(4)-(2)$ & $(2)-(1)$ & (3)-(1) & (4)-(3) & $\begin{array}{l}\text { Mean of } \\
\text { (4)-(2), (3)-(1) }\end{array}$ & $\begin{array}{l}\text { Mean of } \\
(2)-(1),(4)-(3)\end{array}$ \\
\hline \multicolumn{13}{|l|}{ Inequality } \\
\hline Gini & 33.75 & 33.75 & 34.10 & 34.72 & 35.09 & 1.34 & 0.99 & 0.35 & 0.97 & 0.37 & 0.98 & 0.36 \\
\hline P90/P10 & 5.87 & 5.87 & 5.93 & 5.96 & 6.02 & 0.15 & 0.08 & 0.07 & 0.09 & 0.06 & 0.09 & 0.06 \\
\hline P90/P50 & 1.96 & 1.96 & 1.98 & 2.00 & 2.02 & 0.06 & 0.04 & 0.02 & 0.04 & 0.02 & 0.04 & 0.02 \\
\hline P50/P10 & 3.00 & 3.00 & 3.00 & 2.98 & 2.98 & -0.02 & -0.01 & 0.00 & -0.01 & 0.00 & -0.01 & 0.00 \\
\hline
\end{tabular}

Measures are based on equivalized income using the square-root of househohld size scale. Gini multiplied by 100. Uprating according to the level of mean nominal earnings growth. 
Table 4: Decomposing changes in income distribution over time (cont.)

\begin{tabular}{|c|c|c|c|c|c|c|c|c|c|c|c|c|}
\hline \multirow{3}{*}{$\begin{array}{l}\text { data year: } \\
\text { uprated to: } \\
\text { policy year: } \\
\text { uprated to: }\end{array}$} & \multirow{2}{*}{$\begin{array}{l}1989 \\
1989\end{array}$} & $\begin{array}{l}1989 \\
1994\end{array}$ & \multirow{2}{*}{$\begin{array}{l}1994 \\
1989\end{array}$} & \multirow{2}{*}{$\begin{array}{l}1989 \\
1994 \\
1994\end{array}$} & \multirow{2}{*}{$\begin{array}{l}1994 \\
1994\end{array}$} & \multirow{2}{*}{$\begin{array}{c}\text { Total } \\
\text { change }\end{array}$} & \multicolumn{4}{|c|}{ Decomposition I Decomposition II } & \multicolumn{2}{|c|}{$\begin{array}{c}\text { Shorrocks-Shapley } \\
\text { Decomposition }\end{array}$} \\
\hline & & $\begin{array}{l}1989 \\
1994\end{array}$ & & & & & $\begin{array}{c}\text { Tax } \\
\text { policy } \\
\text { effect }\end{array}$ & $\begin{array}{l}\text { Other } \\
\text { effect }\end{array}$ & $\begin{array}{c}\text { Tax } \\
\text { policy } \\
\text { effect }\end{array}$ & $\begin{array}{l}\text { Other } \\
\text { effect }\end{array}$ & $\begin{array}{l}\text { Tax policy } \\
\text { effect }\end{array}$ & Other effect \\
\hline & $(0)$ & (1) & (2) & (3) & (4) & (4)-(0) & (4)-(2) & $(2)-(1)$ & (3)-(1) & $(4)-(3)$ & $\begin{array}{l}\text { Mean of } \\
(4)-(2),(3)-(1)\end{array}$ & $\begin{array}{l}\text { Mean of } \\
(2)-(1),(4)-(3)\end{array}$ \\
\hline \multicolumn{13}{|l|}{ Inequality } \\
\hline Gini & 35.38 & 35.38 & 37.20 & 34.69 & 36.64 & 1.26 & -0.56 & 1.82 & -0.69 & 1.95 & -0.63 & 1.89 \\
\hline P90/P10 & 5.87 & 5.87 & 6.43 & 5.61 & 6.13 & 0.26 & -0.30 & 0.57 & -0.26 & 0.52 & -0.28 & 0.54 \\
\hline P90/P50 & 2.02 & 2.02 & 2.09 & 2.01 & 2.09 & 0.07 & -0.01 & 0.07 & -0.01 & 0.07 & -0.01 & 0.07 \\
\hline P50/P10 & 2.90 & 2.90 & 3.07 & 2.79 & 2.94 & 0.03 & -0.14 & 0.17 & -0.11 & 0.15 & -0.12 & 0.16 \\
\hline
\end{tabular}

Measures are based on equivalized income using the square-root of househohld size scale. Gini multiplied by 100. Uprating according the level of price inflation.

\begin{tabular}{|c|c|c|c|c|c|c|c|c|c|c|c|c|}
\hline \multirow{3}{*}{$\begin{array}{l}\text { data year: } \\
\text { uprated to: } \\
\text { policy year: } \\
\text { uprated to: }\end{array}$} & \multirow{2}{*}{$\begin{array}{l}2000 \\
2000\end{array}$} & \multirow{2}{*}{$\begin{array}{l}2000 \\
2004 \\
2000 \\
2004\end{array}$} & $\begin{array}{r}2004 \\
2000\end{array}$ & \multirow{2}{*}{$\begin{array}{l}2000 \\
2004 \\
2004\end{array}$} & \multirow{2}{*}{$\begin{array}{l}2004 \\
2004\end{array}$} & \multirow{2}{*}{$\begin{array}{c}\text { Total } \\
\text { change }\end{array}$} & \multicolumn{4}{|c|}{ Decomposition I Decomposition II } & \multicolumn{2}{|c|}{$\begin{array}{c}\text { Shorrocks-Shapley } \\
\text { Decomposition }\end{array}$} \\
\hline & & & $\begin{array}{l}2000 \\
2004\end{array}$ & & & & $\begin{array}{c}\text { Tax } \\
\text { policy } \\
\text { effect }\end{array}$ & $\begin{array}{l}\text { Other } \\
\text { effect }\end{array}$ & $\begin{array}{c}\text { Tax } \\
\text { policy } \\
\text { effect }\end{array}$ & $\begin{array}{l}\text { Other } \\
\text { effect }\end{array}$ & $\begin{array}{c}\text { Tax policy } \\
\text { effect }\end{array}$ & Other effect \\
\hline & $(0)$ & (1) & (2) & (3) & (4) & (4)-(0) & (4)-(2) & $(2)-(1)$ & $(3)-(1)$ & (4)-(3) & $\begin{array}{l}\text { Mean of } \\
(4)-(2),(3)-(1)\end{array}$ & $\begin{array}{l}\text { Mean of } \\
(2)-(1),(4)-(3)\end{array}$ \\
\hline \multicolumn{13}{|l|}{ Inequality } \\
\hline Gini & 35.86 & 35.86 & 37.25 & 36.12 & 37.57 & 1.71 & 0.32 & 1.39 & 0.26 & 1.45 & 0.29 & 1.42 \\
\hline $\mathrm{P} 90 / \mathrm{P} 10$ & 5.53 & 5.53 & 5.99 & 5.61 & 6.03 & 0.51 & 0.04 & 0.46 & 0.08 & 0.43 & 0.06 & 0.44 \\
\hline P90/P50 & 2.05 & 2.05 & 2.12 & 2.08 & 2.14 & 0.09 & 0.02 & 0.06 & 0.02 & 0.06 & 0.02 & 0.06 \\
\hline P50/P10 & 2.69 & 2.69 & 2.83 & 2.70 & 2.82 & 0.13 & -0.01 & 0.14 & 0.01 & 0.12 & 0.00 & 0.13 \\
\hline
\end{tabular}

Measures are based on equivalized income using the square-root of househohld size scale. Gini multiplied by 100. Uprating according the level of price inflation. 
Figure 1: Average tax rates 1978-2009

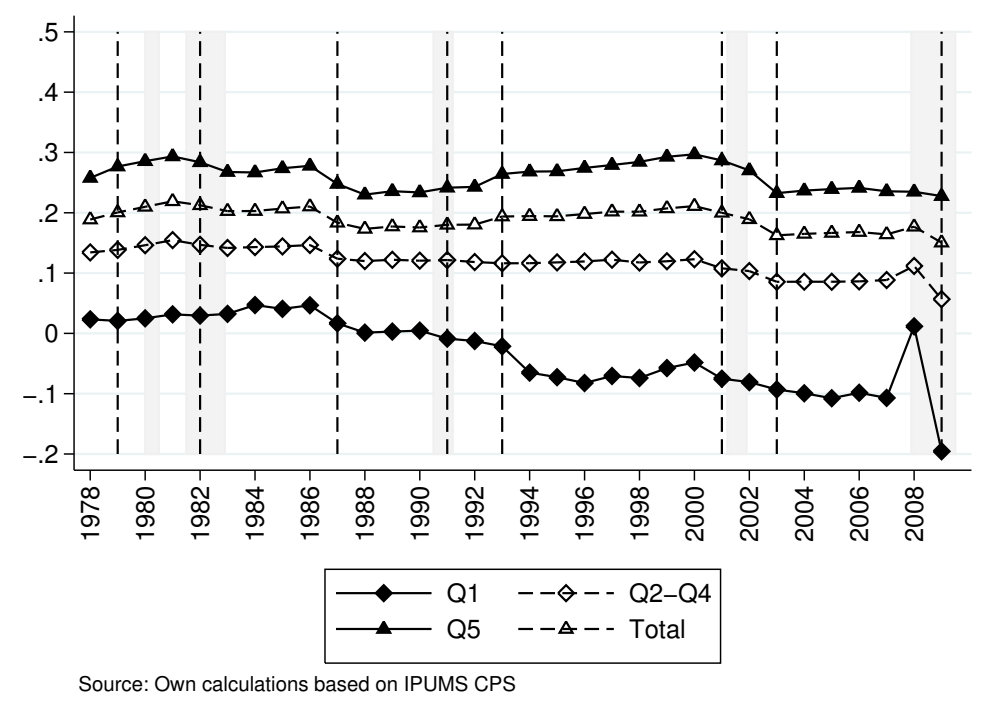

Note: The dashed vertical lines indicate the start of implementation of significant changes in tax legislation (section 3.4). Shaded areas show recession periods (NBER classification). 
Figure 2: Trends in market income

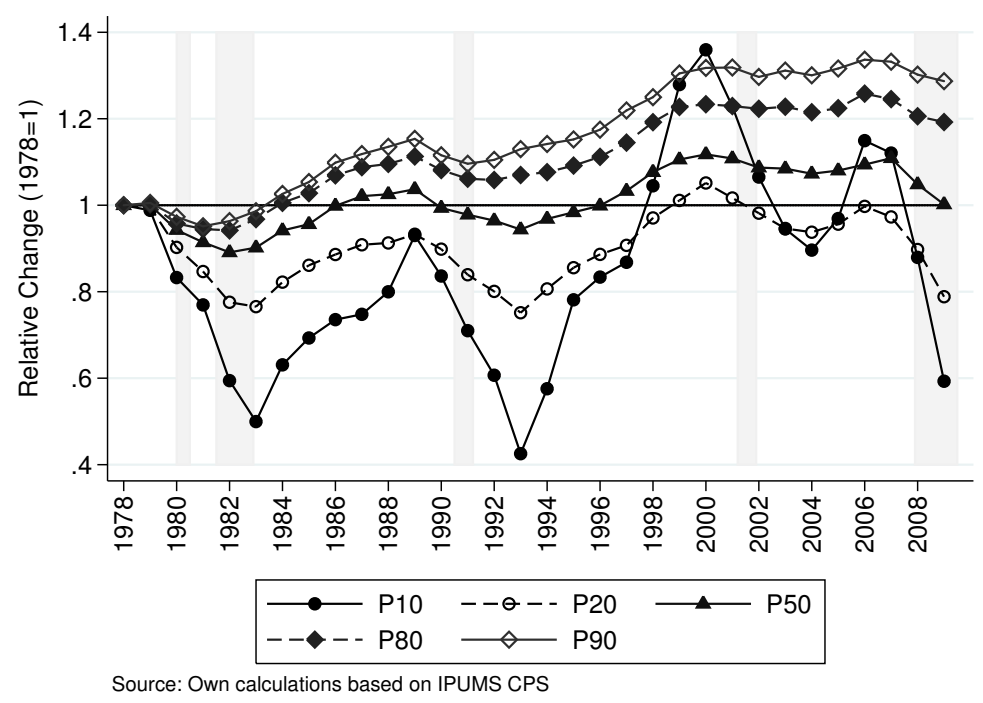

Note: Change in market income (i.e., labor + capital income) relative to base year 1978. Shaded areas show recession periods (NBER classification).

Figure 3: Income inequality 1978-2009

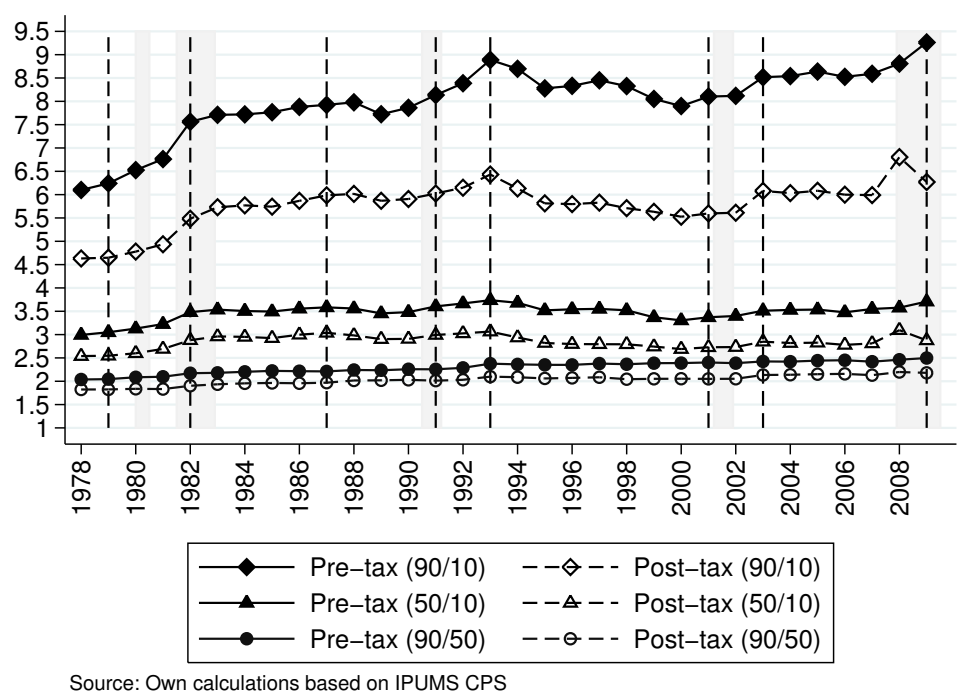

Note: The dashed vertical lines indicate the start of implementation of significant changes in tax legislation (section 3.4). Shaded areas show recession periods (NBER classification). 
Figure 4: Absolute inequality and redistribution trends - 90/10

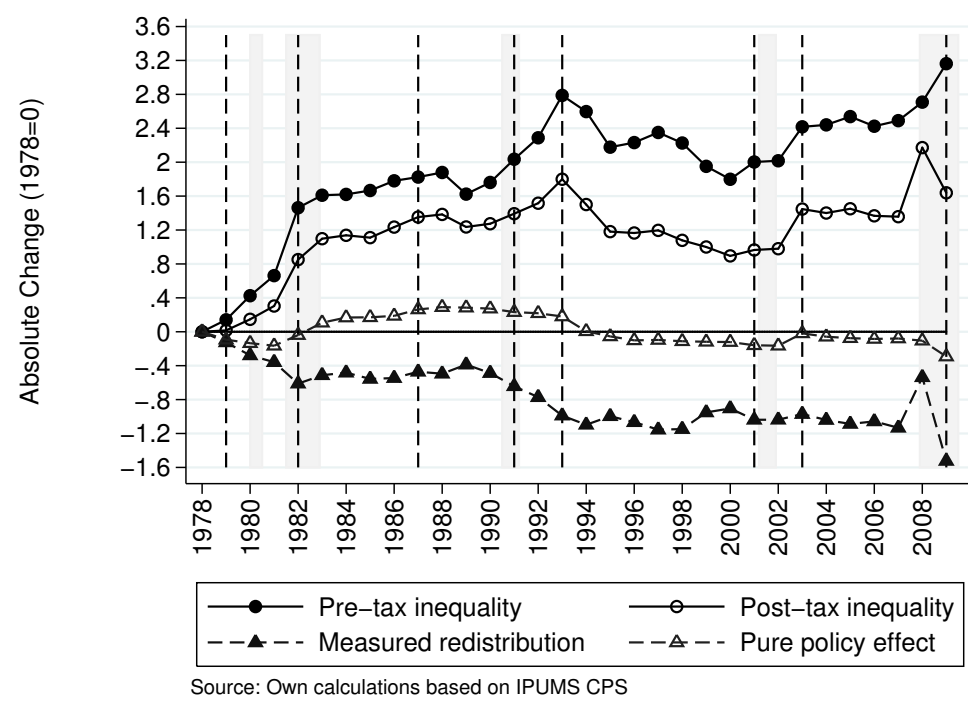

Note: The dashed vertical lines indicate the start of implementation of significant changes in tax legislation (section 3.4). Shaded areas show recession periods (NBER classification).

Figure 5: Absolute inequality and redistribution trends - 90/10 - Imputation of itemized deductions. 1978-2006

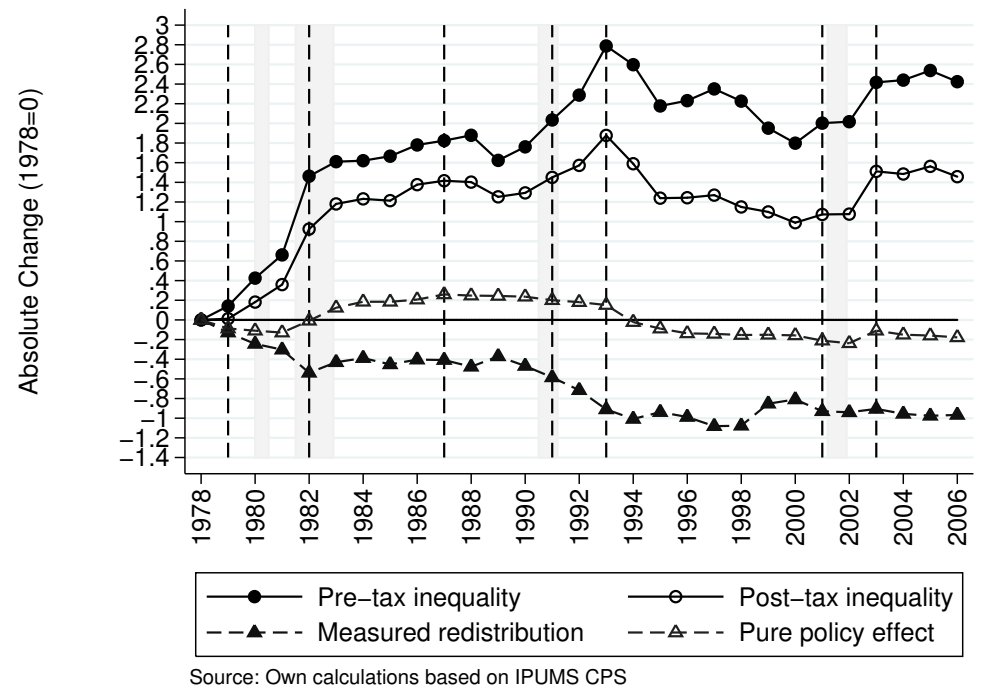

Note: The dashed vertical lines indicate the start of implementation of significant changes in tax legislation (section 3.4). Shaded areas show recession periods (NBER classification). 
Figure 6: Absolute inequality and redistribution trends - 90/50

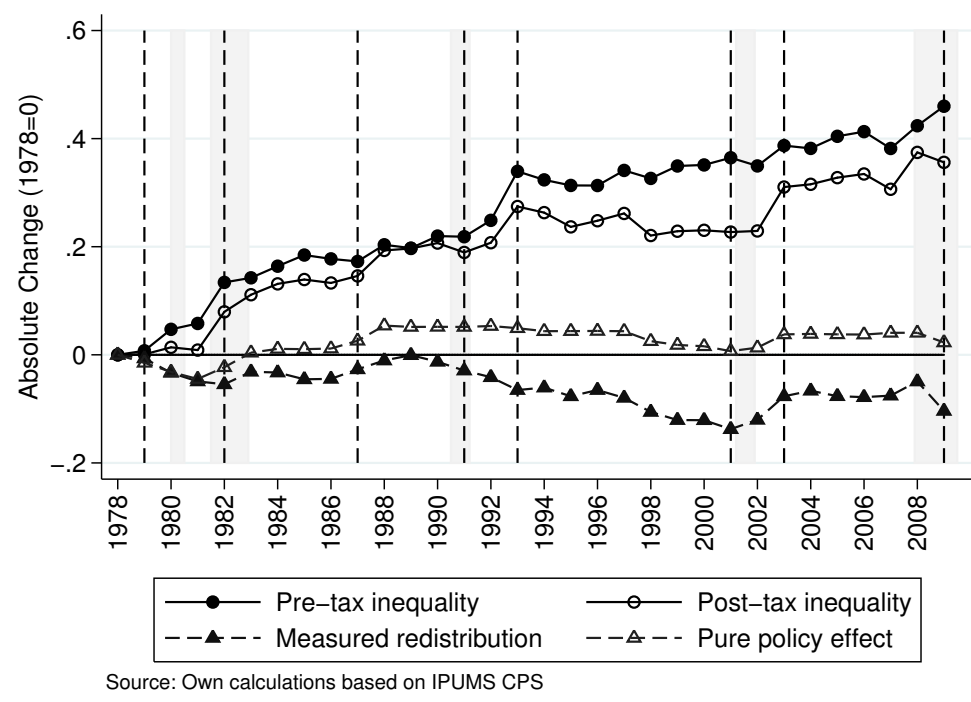

Note: The dashed vertical lines indicate the start of implementation of significant changes in tax legislation (section 3.4). Shaded areas show recession periods (NBER classification).

Figure 7: Absolute inequality and redistribution trends - 50/10

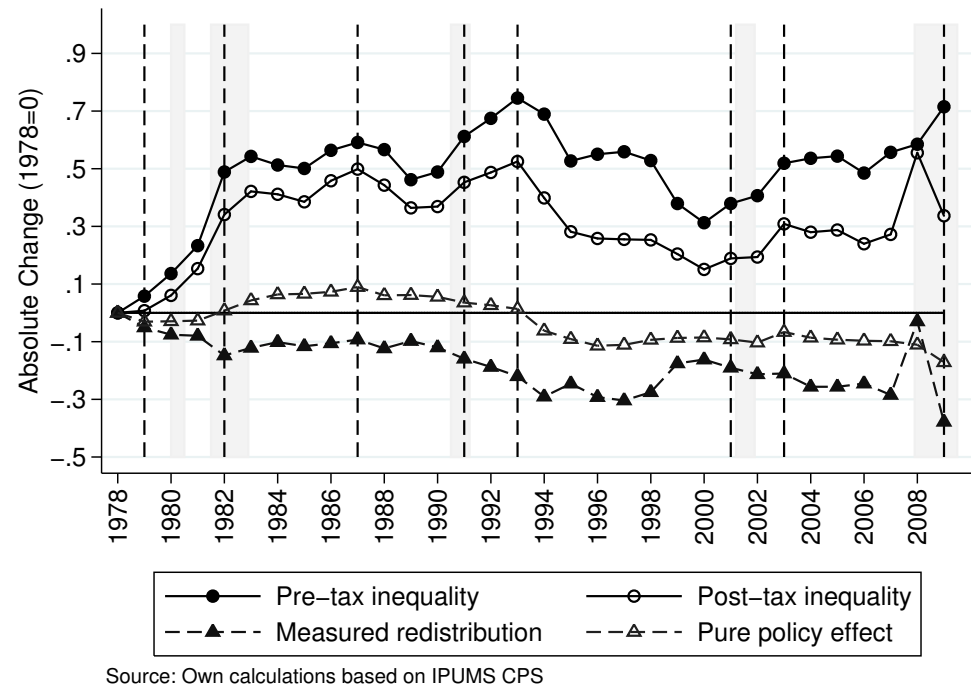

Note: The dashed vertical lines indicate the start of implementation of significant changes in tax legislation (section 3.4). Shaded areas show recession periods (NBER classification). 
Figure 8: Absolute inequality and redistribution trends - Gini

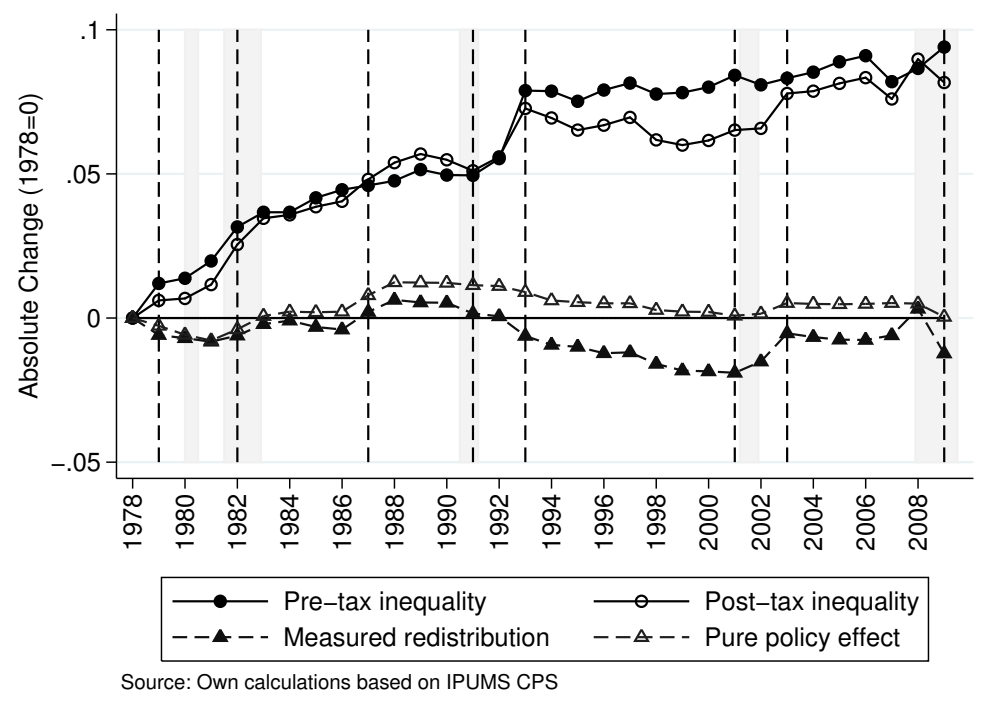

Note: The dashed vertical lines indicate the start of implementation of significant changes in tax legislation (section 3.4). Shaded areas show recession periods (NBER classification).

Figure 9: Policy effect on average tax rates

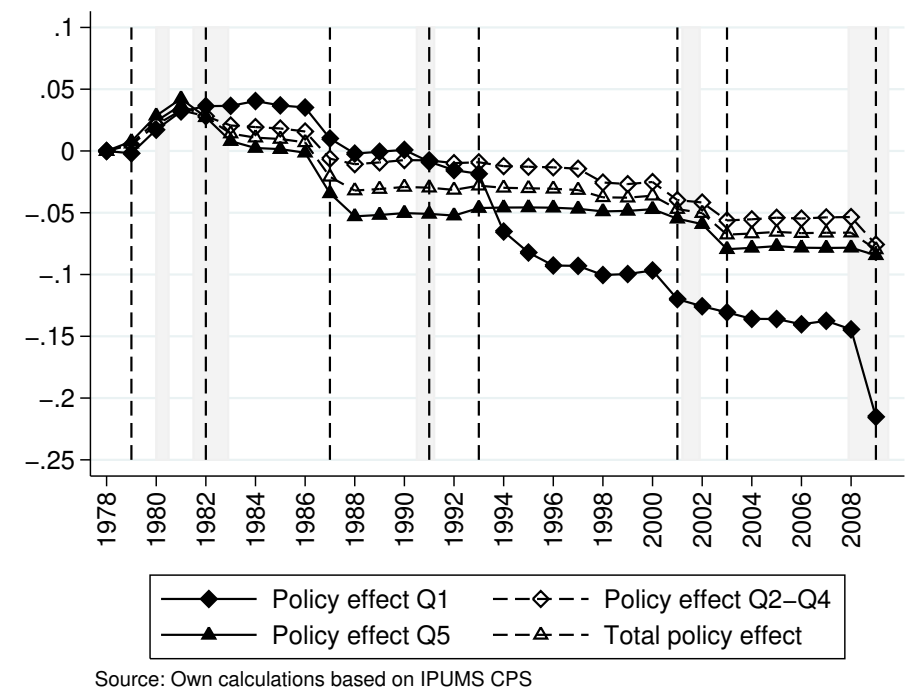

Note: The series show the cumulative policy effect on average tax rates in percentage points. The dashed vertical lines indicate the start of implementation of significant changes in tax legislation (section 3.4). Shaded areas show recession periods (NBER classification). 
Figure 10: Shapley-value policy and other effects 90/10

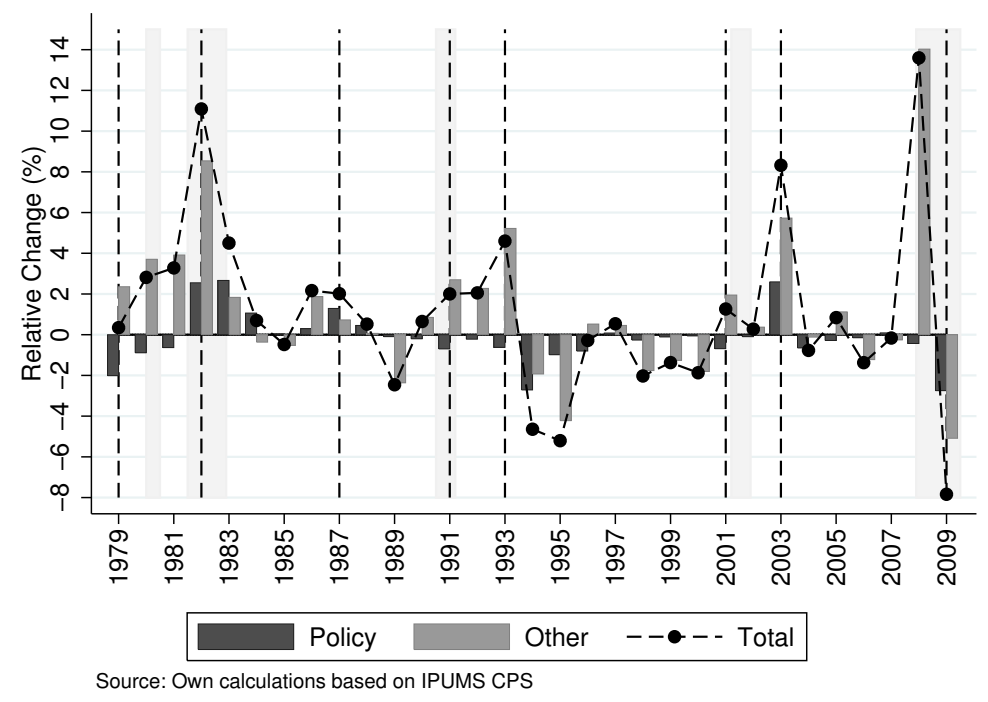

Note: Figure shows direct policy and other effect. Interpretation of policy effect:

Hypothetical percentage change in post-tax income inequality compared to the previous year if only tax parameters, tax base or brackets had changed. Other effect: Hypothetical percentage change in post-tax income inequality compared to the previous year if only the pre-tax income distribution had changed, but policy parameters were fixed. The dashed vertical lines indicate the start of implementation of significant changes in tax legislation (section 3.4). Shaded areas show recession periods (NBER classification). 
Figure 11: Shapley-value policy and other effects $90 / 50$

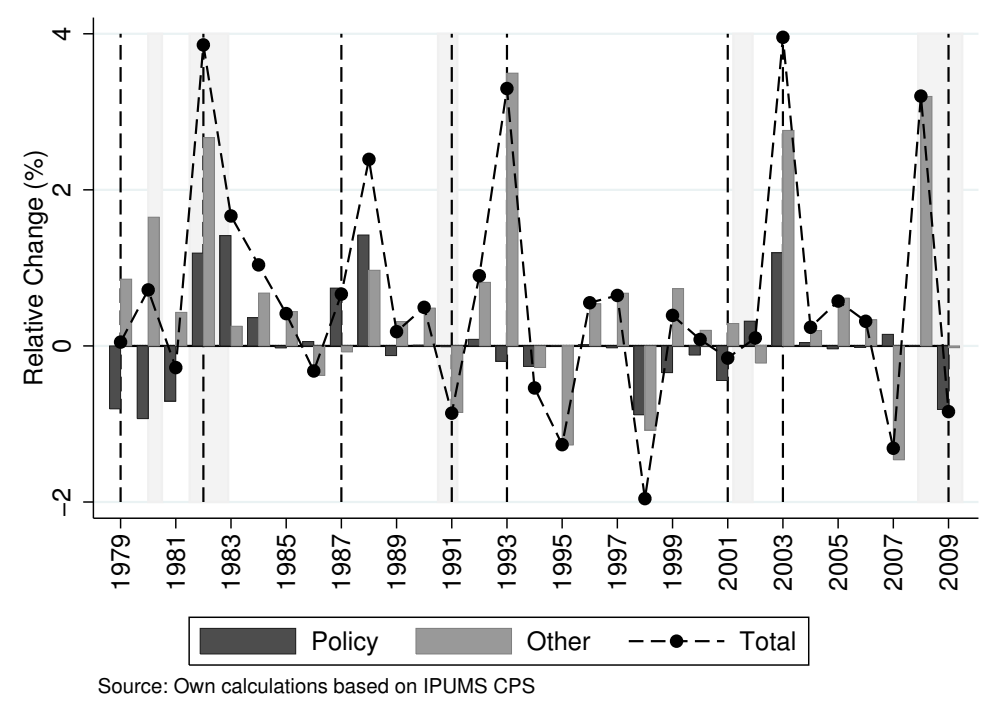

Note: Figure shows direct policy and other effect, see Figure 8.

Figure 12: Shapley-value policy and other effects 50/10

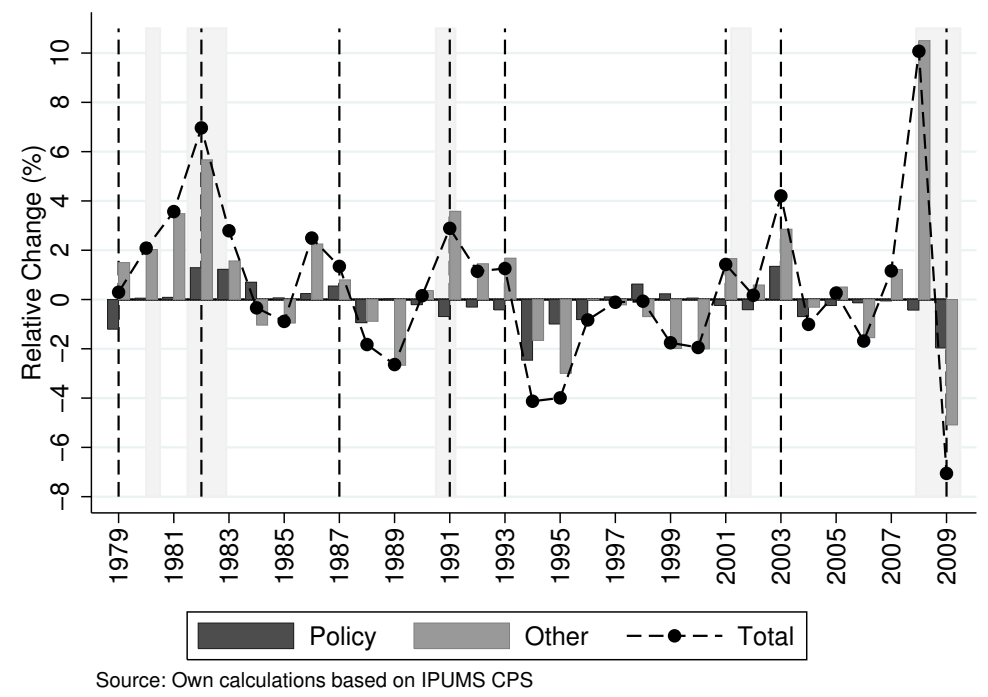

Note: Figure shows direct policy and other effect, see Figure 8. 
Figure 13: Shapley-value policy and other effects Gini

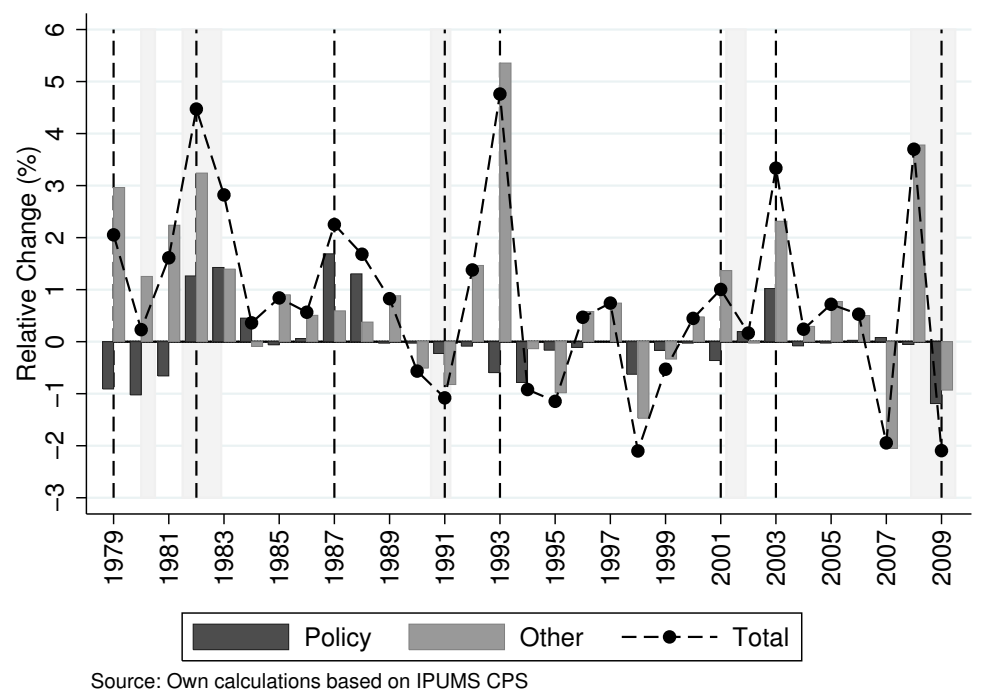

Note: Figure shows direct policy and other effect, see Figure 8.

Figure 14: Shapley-value policy effect

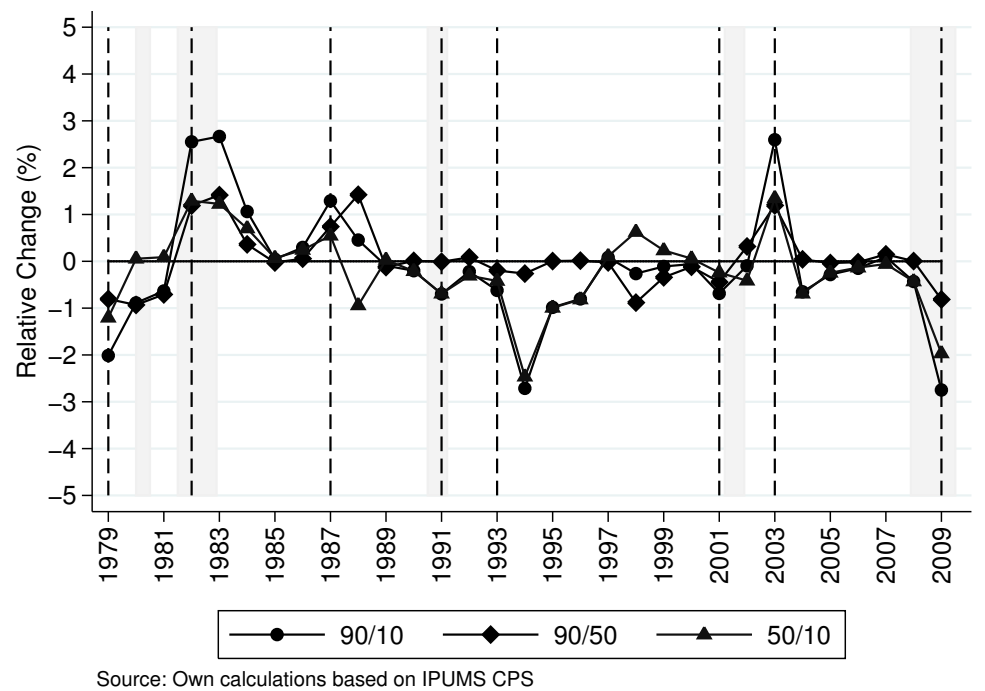

Note: Figure shows direct policy effect for all three inequality measures, see Figure 8. 